\title{
Summary of First-Year Operations and Performance of the Utica Aquifer and North Lake Basin Wetlands Restoration Project in October 2004-November 2005
}

prepared by

Environmental Science Division

Argonne National Laboratory 
About Argonne National Laboratory

Argonne is a U.S. Department of Energy laboratory managed by The University of Chicago

under contract W-31-109-Eng-38. The Laboratory's main facility is outside Chicago, at

9700 South Cass Avenue, Argonne, Illinois 60439. For information about Argonne,

see www.anl.gov.

\section{Availability of This Report}

This report is available, at no cost, at http://www.osti.gov/bridge. It is also available

on paper to the U.S. Department of Energy and its contractors, for a processing fee, from:

U.S. Department of Energy

Office of Scientific and Technical Information

P.O. Box 62

Oak Ridge, TN 37831-0062

phone (865) 576-8401

fax (865) 576-5728

reports@adonis.osti.gov

\section{Disclaimer}

This report was prepared as an account of work sponsored by an agency of the United States Government. Neither the United States Government nor any agency thereof, nor The University of Chicago, nor any of their employees or officers, makes any warranty, express or implied, or assumes any legal liability or responsibility for the accuracy, completeness, or usefulness of any information, apparatus, product, or process disclosed, or represents that its use would not infringe privately owned rights. Reference herein to any specific commercial product, process, or service by trade name, trademark, manufacturer, or otherwise, does not necessarily constitute or imply its endorsement, recommendation, or favoring by the United States Government or any agency thereof. The views and opinions of document authors expressed herein do not necessarily state or reflect those of the United States Government or any agency thereof, Argonne National Laboratory, or The University of Chicago. 


\section{Summary of First-Year Operations and Performance of the Utica Aquifer and North Lake Basin Wetlands Restoration Project in October 2004-November 2005}

by

Applied Geosciences and Environmental Management Section

Environmental Science Division, Argonne National Laboratory

December 2005 


\section{Contents}

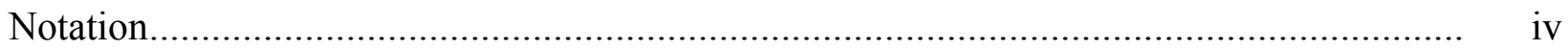

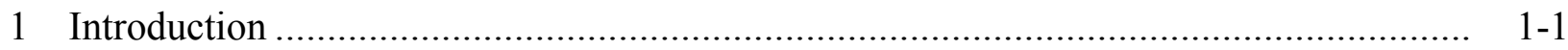

2 Overview of the Aquifer Restoration Facilities at Utica................................................ 2-1

2.1 Wells GWEX1-GWEX3 and the Spray Irrigation Treatment Units ...................... 2-1

2.2 Well GWEX4 and the Conventional Air Stripper ................................................ 2-2

3 Overview of System Operations ............................................................................ 3-1

3.1 Operation of Wells GWEX1-GWEX3 and the Spray Irrigation Treatment Units... 3-1

3.2 Operation of Well GWEX4 and the Conventional Air Stripper ............................. 3-2

4 Groundwater Production Results ............................................................................ 4-1

$4.1 \quad$ Production by Wells GWEX1-GWEX3 ………............................................ 4-1

4.2 Production by Well GWEX4 ……...........................................................

5 Groundwater Treatment Results ............................................................................ $5-1$

5.1 Results for Wells GWEX1-GWEX3, with Treatment by Spray Irrigation ............. 5-2

5.2 Results for Well GWEX4, with Treatment by Air Stripping ................................ 5-5

5.3 Estimated Removal of Carbon Tetrachloride from the Utica Aquifer .................... 5-5

6 Operation, Maintenance, and System Modifications ..................................................... 6-1

6.1 Wells GWEX1-GWEX3 and the Spray Irrigation Treatment Units ....................... 6-1

6.2 Well GWEX4 and the Air Stripping Unit ........................................................ 6-2

6.3 Installation and Sampling of Monitoring Wells.............................................. 6-2

6.4 First-Year Operating and Maintenance Costs.................................................. 6-3

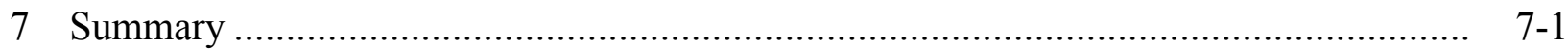

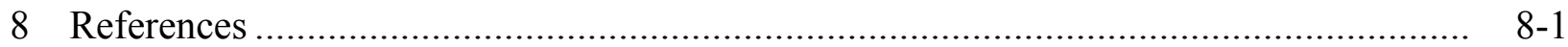

Appendix A： Well Registration Forms ..................................................................... A-1

\section{Figures}

2.1 Locations of the restoration facilities, contaminant plume, and permanent monitoring wells at Utica

2.2 Spray irrigation unit in operation at Utica. 


\section{Tables}

2.1 Summary of construction details for GWEX wells at Utica ..................................... 2-1

4.1 GWEX operation and groundwater production data for the first year of restoration at Utica....

5.1 Analytical results for carbon tetrachloride in untreated groundwater samples and treated effluent samples

5.2 Values for $\mathrm{pH}$ in untreated groundwater samples and treated effluent samples

5.3 Estimation of carbon tetrachloride removed from the Utica aquifer

6.1 Well construction data and analytical results for carbon tetrachloride in groundwater samples from the permanent monitoring wells

6.2 Summary of first-year operating and maintenance costs for the Utica restoration project 
Utica First-Year Review, October 2004-November 2005

Version 00, 12/12/05

\section{Notation}

BGL below ground level

$\mathrm{CCC}$

${ }^{\circ} \mathrm{F}$

$\mathrm{ft}$

gal

gpm

GWEX

$\mathrm{hr}$

$\mu \mathrm{g} / \mathrm{L}$

mph

MW

NDEQ

NGPC

NPDES

USDA

VOC
Commodity Credit Corporation

degree(s) Fahrenheit

foot (feet)

gallon(s)

gallon(s) per minute

groundwater extraction

hour(s)

microgram(s) per liter

mile(s) per hour

monitoring well

Nebraska Department of Environmental Quality

Nebraska Game and Parks Commission

National Pollutant Discharge Elimination System

U.S. Department of Agriculture

volatile organic compound 


\section{Summary of First-Year Operations and Performance of the Utica Aquifer and North Lake Basin Wetlands Restoration Project in October 2004-November 2005}

\section{Introduction}

This document summarizes the performance of the groundwater restoration systems installed by the Commodity Credit Corporation of the U.S. Department of Agriculture (CCC/USDA) at the former CCC/USDA grain storage facility in Utica, Nebraska, during the initial period of system operation, from October 29, 2004, until November 31, 2005.

In the project at Utica, the CCC/USDA is cooperating with multiple state and federal agencies to remove carbon tetrachloride contamination from a shallow aquifer underlying the town and to provide supplemental treated groundwater for use in the restoration of a nearby wetlands area. Argonne National Laboratory has assisted the CCC/USDA by providing technical oversight for the aquifer restoration effort and facilities during this review period.

This document presents overviews of the aquifer restoration facilities (Section 2) and system operations (Section 3), then describes groundwater production results (Section 4), groundwater treatment results (Section 5), and modifications and costs during the review period (Section 6). Section 7 summarizes the first year of operation. 


\section{Overview of the Aquifer Restoration Facilities at Utica}

The principal components of the groundwater restoration systems at Utica are shown in Figure 2.1. The facilities consist of two main operating units, as described below. The facilities include four groundwater extraction (GWEX) wells. Table 2.1 summarizes construction details for these wells. The well registration forms are in Appendix A.

\subsection{Wells GWEX1-GWEX3 and the Spray Irrigation Treatment Units}

Extraction wells GWEX1-GWEX3, located in the northern portion of the town, are used to extract contaminated groundwater from the upgradient portion of the contaminant plume. The wells are linked by a distribution system that selectively carries untreated groundwater to either of two discharge points in the northern and southern subbasins of the North Lake Basin Wildlife Management Area (Figure 2.1). At each discharge point, the water is treated to remove carbon tetrachloride by using a custom spray irrigation treatment unit (Figure 2.2). The three extraction wells are operated simultaneously to maintain a critical operating pressure at each treatment unit.

Wells GWEX1-GWEX3 are operated intermittently during the year, subject to local weather conditions and in consultation with the Nebraska Game and Parks Commission (NGPC). NGPC owns most of the property occupied by the wetlands and has administrative and technical responsibility for management of the wildlife area.

TABLE 2.1 Summary of construction details for GWEX wells at Utica.

\begin{tabular}{lcccc}
\hline & \multicolumn{3}{c}{ Depth (ft BGL) } & \\
\cline { 2 - 4 } Well & Depth & $\begin{array}{c}\text { Screen } \\
\text { Interval }\end{array}$ & $\begin{array}{c}\text { Gravel } \\
\text { Pack } \\
\text { Interval }\end{array}$ & $\begin{array}{c}\text { Casing } \\
\text { Diameter } \\
\text { (in.) }\end{array}$ \\
\hline GWEX1 & 132 & $106-126$ & $97-132$ & 8 \\
GWEX2 & 148 & $110-145$ & $106-148$ & 8 \\
GWEX3 & 146 & $105-140$ & $101-146$ & 8 \\
GWEX4 & 150 & $115-145$ & $110-150$ & 6 \\
\hline
\end{tabular}




\subsection{Well GWEX4 and the Conventional Air Stripper}

Extraction well GWEX4 is located near the downgradient toe of the carbon tetrachloride plume and is operated continuously as a containment well. Groundwater produced from GWEX4 is treated by using a conventional (shallow-tray) air stripping technique, and the effluent is discharged to the surface for reinfiltration into the shallow Utica aquifer. 
Utica First-Year Review, October 2004-November 2005

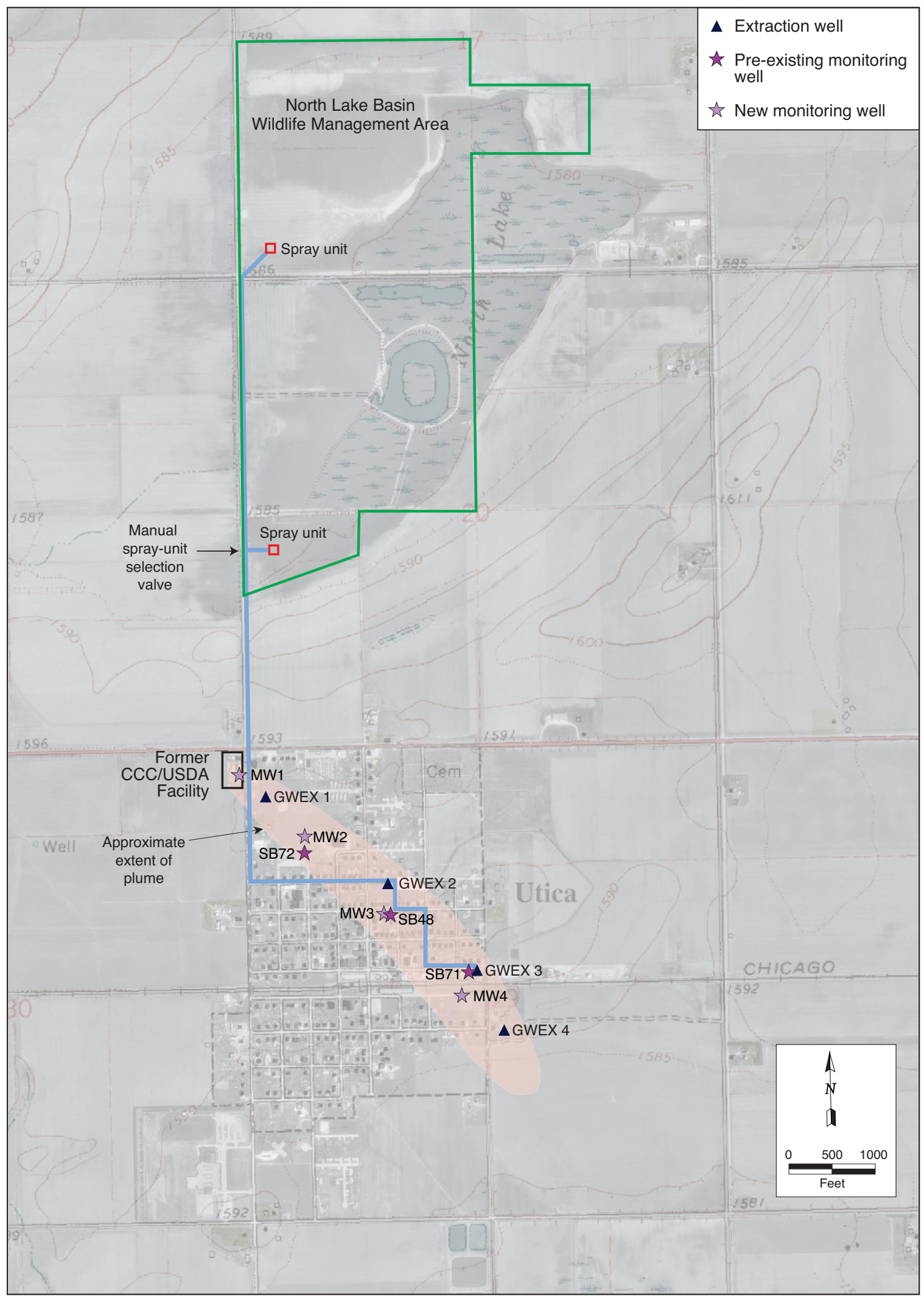

FIGURE 2.1 Locations of the restoration facilities, contaminant plume, and permanent monitoring wells at Utica. 


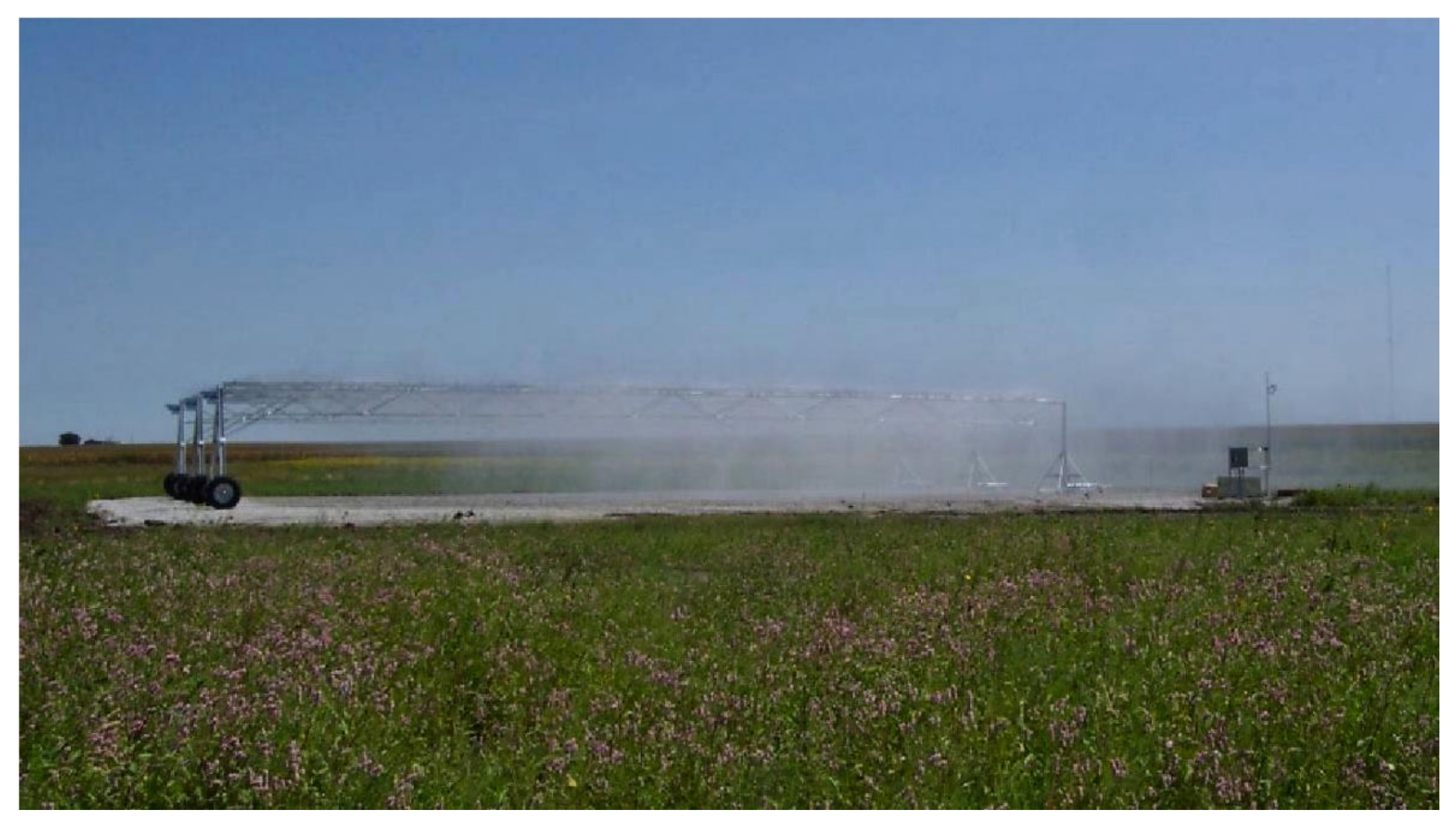

FIGURE 2.2 Spray irrigation unit in operation at Utica 


\section{Overview of System Operations}

\subsection{Operation of Wells GWEX1-GWEX3 and the Spray Irrigation Treatment Units}

Routine operation of wells GWEX1-GWEX3 and the spray irrigation treatment units began on November 22, 2004. The wells were pumped intermittently, under automated control, during 11 of the 13 months during the review period. The daily operation of the spray treatment units is governed primarily by weather conditions; to ensure effective removal of the carbon tetrachloride and to prevent excessive drift of the resulting spray discharge, a minimum air temperature of $40^{\circ} \mathrm{F}$ and sustained winds of less than $15 \mathrm{mph}$ are required for operation.

Wells GWEX1-GWEX3 and the treatment units were not operated in late May 2005 and all of June and July 2005, because heavy storms in early May caused rapid, widespread flooding throughout the Utica area and persistent high water levels in the North Lake Basin and on surrounding private properties. The pumping was curtailed at the request of the NGPC, in response to concerns expressed by the neighboring property owners regarding the continued flooding.

For reasons including apparent power supply fluctuations and outages, unexpected shutdowns of the wells and the spray treatment units occurred sporadically during the review period. Investigations to determine the quality of the electrical power supplied by the local utility company led to adjustments to the drive units for the well pumps that reduced the frequency of shutdowns. Occasional pumping interruptions have continued, however. Investigation into the cause(s) of these shutdowns were still in progress at the end of the review period.

Treated groundwater from the spray irrigation systems was selectively routed to both the north and south subbasins at the request of the NGPC. Groundwater was discharged exclusively to the north subbasin during the winter of 2004 and early spring of 2005, then to both subbasins during the remainder of the review period. 


\subsection{Operation of Well GWEX4 and the Conventional Air Stripper}

Operation of well GWEX4 and the associated air stripper began on October 29, 2004. GWEX4 operated continuously during the review period, with only two brief interruptions of less than one day each. The interruptions were as follows:

- On August 12, 2005, the equipment was temporarily shut down to permit the local utility company to repair power supply connections to the well house.

- On October 26, 2005, the system was shut down for routine inspection and cleaning of the shallow-tray air stripping unit.

Treated groundwater from well GWEX4 is discharged to an open ditch that serves as part of Utica's storm drainage system. The ditch borders a county road leading eastward from the town, as well as an adjacent private farm property. During the review period, Argonne received no reports of drainage or other problems associated with discharge from GWEX4. 


\section{Groundwater Production Results}

The volumes of groundwater extracted from the Utica aquifer, treated, and discharged are summarized in Table 4.1.

\subsection{Production by Wells GWEX1-GWEX3}

Wells GWEX1-GWEX3 are equipped with electronically controlled pump drive units linked to digital flow meters that automatically and continuously adjust the flow from each well to maintain user-specified pumping rates. The programmed flow rates for these wells were as follows:

- $\quad$ GWEX1, 50 gpm

- $\quad$ GWEX2, 180-200 gpm

- $\quad$ GWEX3, 125 gpm

The selected rates were achieved, within \pm 1 gpm, throughout the review period.

Wells GWEX1-GWEX3 were pumped for approximately 1,560 hr during the review period and discharged approximately 34.6 million gallons (106 acre-feet) of treated water to the North Lake Basin wetlands. Approximately $64 \%$ of the total production was routed to the northern wetlands subbasin, at the request of the NGPC.

\subsection{Production by Well GWEX4}

Measured groundwater pumping rates (determined from an inline flow meter) at GWEX4 ranged from approximately $51 \mathrm{gpm}$ to $64 \mathrm{gpm}$. Periodically, the rates were adjusted manually to compensate for a very slow decline in the flow rate from the well over time. The groundwater volumes pumped in any one complete month (Table 4.1) ranged from approximately 2.1 million gallons to 2.7 million gallons. A total of 31.7 million gallons (97.5 acre-feet) of groundwater was treated and discharged during the review period, at a net average pumping rate of approximately 56 gpm. 
Utica First-Year Review, October 2004-November 2005

Version 00, 12/12/05

TABLE 4.1 GWEX operation and groundwater production data for the first year of restoration at Utica. ${ }^{2}$

\begin{tabular}{|c|c|c|c|c|c|c|c|c|}
\hline \multirow[b]{3}{*}{ Month } & \multirow{2}{*}{\multicolumn{3}{|c|}{$\begin{array}{l}\text { Groundwater Produced by } \\
\text { Wells GWEX1-GWEX3 }{ }^{\mathrm{b}} \text { (gal) }\end{array}$}} & \multirow{3}{*}{$\begin{array}{c}\text { Operating } \\
\text { Time } \\
\text { GWEX1-3c } \\
\text { (hr) }\end{array}$} & \multirow{2}{*}{\multicolumn{2}{|c|}{$\begin{array}{l}\text { Volume Discharged to } \\
\text { Wetlands (gal) }\end{array}$}} & \multicolumn{2}{|c|}{ GWEX $4^{d}$} \\
\hline & & & & & & & \multirow{2}{*}{$\begin{array}{l}\text { Groundwater } \\
\text { Produced } \\
\text { (gal) }\end{array}$} & \multirow{2}{*}{$\begin{array}{c}\text { Operatin } \\
\text { Time } \\
\text { (days) }\end{array}$} \\
\hline & GWEX1 & GWEX2 & GWEX3 & & North & South & & \\
\hline Oct 2004 & $\_^{\mathrm{e}}$ & - & - & - & - & - & 263,520 & 3 \\
\hline Nov 2004 & 130,800 & 470,880 & 327,000 & 43.6 & 928,680 & - & $2,687,040$ & 30 \\
\hline Dec 2004 & 151,800 & 546,480 & 379,500 & 50.6 & $1,077,780$ & - & $2,660,544$ & 31 \\
\hline Jan 2005 & 21,000 & 75,600 & 52,500 & 7.0 & 149,100 & - & $2,544,480$ & 31 \\
\hline Feb 2005 & 288,900 & $1,040,040$ & 722,250 & 96.3 & $2,051,190$ & - & $2,298,240$ & 28 \\
\hline Mar 2005 & 585,300 & $2,107,080$ & $1,463,250$ & 195.1 & $4,155,630$ & - & $2,620,368$ & 31 \\
\hline Apr 2005 & 407,944 & $1,631,776$ & $1,019,860$ & 135.9 & $1,780,680$ & $1,278,900$ & $2,397,600$ & 30 \\
\hline May 2005 & 243,933 & 975,733 & 609,833 & 81.3 & - & $1,829,500$ & $2,410,560$ & 31 \\
\hline Jun 2005 & - & - & - & - & - & - & $2,332,800$ & 30 \\
\hline Jul 2005 & - & - & - & - & - & - & $2,332,800$ & 31 \\
\hline Aug 2005 & 200,827 & 803,307 & 502,067 & 66.9 & $1,506,200$ & - & $2,096,460$ & 31 \\
\hline Sept 2005 & 899,880 & $3,599,520$ & $2,249,700$ & 300.0 & $3,644,514$ & $3,104,586$ & $2,273,000$ & 30 \\
\hline Oct 2005 & $1,201,093$ & $4,804,373$ & $3,002,733$ & 400.5 & $2,648,411$ & $6,359,789$ & $2,455,905$ & 31 \\
\hline Nov 2005 & 546,267 & $2,185,067$ & $1,365,667$ & 182.1 & $4,097,000$ & - & $2,379,375$ & 31 \\
\hline TOTAL & $4,677,744$ & $18,239,856$ & $11,694,360$ & $1,559.3$ & $22,039,185$ & $12,572,775$ & $31,752,692$ & 399 \\
\hline
\end{tabular}

a Combined total production: $66,364,652$ gal. Total production to wetlands: $34,611,960$ gal.

b Routine operation of GWEX1-GWEX3 and the spray irrigation treatment units began on November 22, 2004.

c Wells GWEX1-GWEX3 operate simultaneously.

d Routine operation of GWEX4 and the air stripping unit began on October 29, 2004.

e Unit not in operation. 


\section{Groundwater Treatment Results}

Treated groundwater at Utica is discharged under a National Pollutant Discharge Elimination System (NPDES) Permit, number NE0137456, issued by the Nebraska Department of Environmental Quality (NDEQ) on October 1, 2004.

To comply with the NPDES permit, samples of treated groundwater are collected monthly

- At the outlet of the air stripping unit at GWEX4 and

- From the spray discharge at each of the irrigation treatment units (during months of operation).

The samples are analyzed to determine the residual concentrations of carbon tetrachloride in the treated groundwater and the $\mathrm{pH}$ of the effluent. The results of these analyses are reported to the NDEQ quarterly.

The discharges of treated groundwater at Utica are considered by the NDEQ to contribute to the surface waters of the state. On this basis, NDEQ has specified the following compliance limits for the outfall from each treatment unit:

- A target maximum residual carbon tetrachloride concentration of $44.2 \mu \mathrm{g} / \mathrm{L}$

- An acceptable $\mathrm{pH}$ range of 6.5 to 9.0

In conjunction with the compliance sampling, Argonne collects monthly samples of the untreated groundwater from each extraction well. The samples are analyzed for volatile organic compounds (VOCs) to enable estimation of the following:

- Carbon tetrachloride removal efficiencies for the treatment units

- Quantities of carbon tetrachloride removed from the contaminated aquifer 
The results of the sampling and analyses during the review period are summarized in Tables 5.1 and 5.2.

\subsection{Results for Wells GWEX1-GWEX3, with Treatment by Spray Irrigation}

The concentrations of carbon tetrachloride found in the untreated groundwater from extractions wells GWEX2 and GWEX3 remained fairly stable and showed no clear trends throughout the first year of pumping (Table 5.1). Carbon tetrachloride concentrations in the produced water from GWEX2 ranged from $57 \mu \mathrm{g} / \mathrm{L}$ to $118 \mu \mathrm{g} / \mathrm{L}$; the concentrations at GWEX3 ranged from $88 \mu \mathrm{g} / \mathrm{L}$ to $196 \mu \mathrm{g} / \mathrm{L}$.

Well GWEX1, which is located in the upgradient portion of the identified plume, was constructed to intercept carbon tetrachloride contamination in the upper portion of the Utica aquifer, near the former CCC/USDA grain storage facility. Carbon tetrachloride was not detected in the untreated groundwater from GWEX1 in the first four months of its operation (November 2004-February 2005; Table 5.1); however, contamination began to appear at increasing levels in March-early May 2005, before pumping temporarily ceased during the summer months (see Section 3.1). The concentrations of carbon tetrachloride detected at this well have risen steadily since pumping began again in August 2005. A maximum carbon tetrachloride concentration of $74 \mu \mathrm{g} / \mathrm{L}$ was detected at GWEX1 in November 2005.

The groundwater produced from wells GWEX1-GWEX3 is combined into a single stream for conveyance to the wetlands via a common pipeline. This combined flow is also sampled monthly, as an indicator of the weighted average concentration of carbon tetrachloride in the untreated groundwater supplied to the spray irrigation treatment units. The measured concentrations in the combined flow showed minimal variation during the review period, ranging from $100 \mu \mathrm{g} / \mathrm{L}$ to $122 \mu \mathrm{g} / \mathrm{L}$.

Treated groundwater sprayed from the irrigation units is collected for analysis at the following four locations at the treatment site during each sampling event:

- Beneath the center point of the "west" irrigation span

- Beneath the center point of the "center" irrigation span 
TABLE 5.1 Analytical results for carbon tetrachloride in untreated groundwater samples and treated effluent samples.

Carbon Tetrachloride Concentration $(\mu \mathrm{g} / \mathrm{L})$

\begin{tabular}{|c|c|c|c|c|c|c|c|c|c|c|c|c|c|c|}
\hline \multirow[b]{2}{*}{ Month } & \multicolumn{4}{|c|}{ GWEX1-GWEX3 Untreated } & \multicolumn{4}{|c|}{ North Spray Unit Effluent } & \multicolumn{4}{|c|}{ South Spray Unit Effluent } & \multirow{2}{*}{$\begin{array}{c}\text { GWEX4 } \\
\text { Untreated }\end{array}$} & \multirow{2}{*}{$\begin{array}{l}\text { Stripper } \\
\text { Effluent }\end{array}$} \\
\hline & GWEX1 & GWEX2 & GWEX3 & Mixed $^{\mathrm{a}}$ & West $^{b}$ & Center $^{b}$ & East $^{\mathrm{b}}$ & $\operatorname{Max}{ }^{\mathrm{C}}$ & West $^{b}$ & Center $^{b}$ & East $^{b}$ & $\operatorname{Max}^{\mathrm{C}}$ & & \\
\hline Nov 2004 & $N D^{d}$ & 103 & 160 & 115 & ND & 2.3 & ND & ND & $-^{e}$ & - & - & - & $77-94^{f}$ & ND \\
\hline Dec 2004 & ND & $108-118$ & 98 & 112 & 2.2 & 1.2 & ND & 1.6 & - & - & - & - & 88-95 & ND \\
\hline Jan 2005 & ND & 90 & $175-196$ & 103 & 1.9 & $1.6-1.7$ & 1.6 & 1.3 & - & - & - & - & $74-88$ & ND \\
\hline Feb 2005 & ND & 104 & $133-142$ & 101 & 2.0 & 7.2 & $5.6-6$ & ND & - & - & - & - & $88-94$ & ND \\
\hline Mar 2005 & 2.5 & 135 & $118-143$ & 111 & 1.5 & ND-1.4 & $0.9 \mathrm{Jg}-1.6$ & ND & - & - & - & - & 89-92 & ND \\
\hline Apr 2005 & 20 & $83-87$ & 120 & $100-102$ & 1.8 & 0.4 & $0.7 \mathrm{~J}$ & 1.2 & $4.0-4.2$ & $0.4 \mathrm{~J}-0.5 \mathrm{~J}$ & $0.8 \mathrm{~J}$ & $5.1-5.3$ & $87-91$ & ND \\
\hline May 2005 & 22 & $98-104$ & 121 & 103 & - & - & - & - & $0.4 \mathrm{~J}$ & $0.7 \mathrm{~J}$ & $0.8 \mathrm{~J}$ & $0.6 \mathrm{~J}-0.8 \mathrm{~J}$ & $65-77$ & ND \\
\hline Jun 2005 & - & - & - & - & - & - & - & - & - & - & - & - & $65-68$ & ND \\
\hline Jul 2005 & - & - & - & - & - & - & - & - & - & - & - & - & $66-72$ & ND \\
\hline Aug 2005 & 6.4 & $97-100$ & 144 & 117 & $0.8 \mathrm{~J}$ & $6.1-6.2$ & $0.8 \mathrm{~J}$ & ND & - & - & - & - & $56-58$ & ND \\
\hline Sep 2005 & 37 & 108 & $170-183$ & 115 & $0.7 \mathrm{~J}$ & $0.7 \mathrm{~J}$ & $0.3 \mathrm{~J}$ & $0.3 \mathrm{~J}$ & $1.8-1.9$ & $0.2 \mathrm{~J}$ & $0.4 \mathrm{~J}$ & ND & $62-67$ & ND \\
\hline Oct 2005 & 51 & $57-61$ & 88 & 101 & 1.4 & $0.4 \mathrm{~J}$ & 1.6 & 1.8 & 1.2 & $0.3 \mathrm{~J}$ & $0.5 \mathrm{~J}$ & $0.5 \mathrm{~J}-0.6 \mathrm{~J}$ & $55-57$ & ND \\
\hline Nov 2005 & 74 & $109-114$ & 166 & $114-122$ & 5.0 & 4.0 & 1.7 & $0.7 \mathrm{~J}$ & - & - & - & - & 53 & ND \\
\hline
\end{tabular}

a Analytical results for samples from the combined flows of GWEX1-GWEX3.

b Samples of spray collected below the center point of the respective irrigation span.

c Samples of spray collected at the estimated location of maximum spray outfall.

${ }^{d} \mathrm{ND}$, not detected at a method detection limit of $0.1 \mu \mathrm{g} / \mathrm{L}$.

e Unit not in operation.

$f$ Ranges of values represent both primary samples and quality control replicates and duplicates.

g Qualifier $\mathrm{J}$ indicates an estimated concentration below the quantitation limit of $1 \mu \mathrm{g} / \mathrm{L}$ for the purge-and-trap method. 
TABLE 5.2 Values for $\mathrm{pH}$ in untreated groundwater samples and treated effluent samples.

\begin{tabular}{|c|c|c|c|c|c|c|c|c|}
\hline \multirow[b]{3}{*}{ Month } & \multicolumn{8}{|c|}{$\mathrm{pH}$} \\
\hline & \multicolumn{4}{|c|}{ GWEX1-GWEX3 Untreated } & \multirow{2}{*}{$\begin{array}{l}\text { North } \\
\text { Spray } \\
\text { Unit }^{b}\end{array}$} & \multirow{2}{*}{$\begin{array}{l}\text { South } \\
\text { Spray } \\
\text { Unit }^{b}\end{array}$} & \multirow{2}{*}{$\begin{array}{c}\text { GWEX4 } \\
\text { Untreated }\end{array}$} & \multirow{2}{*}{$\begin{array}{l}\text { Stripper } \\
\text { Effluent }\end{array}$} \\
\hline & GWEX1 & GWEX2 & GWEX3 & Mixed $^{\mathrm{a}}$ & & & & \\
\hline Nov 2004 & $N R^{c}$ & NR & NR & NR & 7.7 & $-d$ & $6.28-6.67^{e}$ & $7.76-8.06$ \\
\hline Dec 2004 & 6.80 & 6.76 & 6.72 & 6.80 & 7.6 & - & 8.23 & 7.01 \\
\hline Jan 2005 & $6.89-7.27$ & $6.86-7.13$ & $7.23-7.24$ & $7.35-7.53$ & $7.82-7.84$ & - & 6.74 & 7.82 \\
\hline Feb 2005 & $6.44-6.62$ & $6.94-7.10$ & 7.07 & $7.15-7.20$ & $7.36-7.68$ & - & 6.29 & 7.82 \\
\hline Mar 2005 & $7.16-7.30$ & $7.10-7.21$ & $7.05-7.21$ & $7.23-7.25$ & $7.98-7.99$ & - & 6.46 & 7.85 \\
\hline Apr 2005 & $6.91-7.00$ & $7.08-7.17$ & $7.02-7.07$ & $7.08-7.18$ & 7.58 & 7.85 & $6.45-6.56$ & $7.83-7.98$ \\
\hline May 2005 & $7.10-7.15$ & $7.09-7.12$ & $7.11-7.22$ & $7.20-7.24$ & - & $7.82-7.90$ & $6.55-6.65$ & $7.93-8.14$ \\
\hline Jun 2005 & - & - & - & - & - & - & $6.90-6.93$ & $8.03-8.34$ \\
\hline Jul 2005 & - & - & - & - & - & - & $6.92-6.95$ & $8.34-8.35$ \\
\hline Aug 2005 & $7.03-7.04$ & $6.90-7.04$ & $6.87-7.18$ & $7.00-7.09$ & $7.46-7.52$ & - & $6.37-6.40$ & $7.83-7.86$ \\
\hline Sep 2005 & $6.93-6.96$ & $6.90-6.96$ & $7.06-7.09$ & $6.77-6.81$ & $7.60-7.73$ & $7.70-7.82$ & $6.28-6.37$ & $7.58-7.69$ \\
\hline Oct 2005 & 7.22 & 7.14 & 7.05 & 7.15 & $7.01-8.12$ & $7.98-8.15$ & $6.30-6.36$ & $7.47-7.73$ \\
\hline Nov 2005 & $7.04-7.11$ & $6.98-6.99$ & $6.97-6.99$ & $6.73-6.87$ & $8.01-8.18$ & - & $6.59-6.78$ & $8.03-8.24$ \\
\hline
\end{tabular}

a Values for samples from the combined flows of GWEX1-GWEX3.

b Average value for spray samples collected at one or more locations at the discharge site.

c NR, not recorded.

d Unit not in operation.

e Ranges indicate $\mathrm{pH}$ values over the sampling period each month.

- Beneath the center point of the "east" irrigation span

- At a fourth location visually chosen to reflect the estimated site of maximum spray outfall ("max" value; position varying from month to month; based on prevailing wind and spray conditions at the time of sampling)

The results summarized in Table 5.1 show that, with only a few exceptions, the concentrations of all spray samples collected during the review period were below the maximum contaminant level of $5.0 \mu \mathrm{g} / \mathrm{L}$ promulgated by the U.S. Environmental Protection Agency for carbon tetrachloride in drinking water. The maximum carbon tetrachloride level identified for a single sample in spray discharged from the irrigation treatment units was $7.2 \mu \mathrm{g} / \mathrm{L}$. The average concentration of carbon tetrachloride in the treated groundwater discharged to the wetlands was $1.45 \mu \mathrm{g} / \mathrm{L}$. The concentrations of carbon tetrachloride in all spray samples were below the 
maximum target concentration $(44.2 \mu \mathrm{g} / \mathrm{L})$ allowed under the NPDES permit, by roughly an order of magnitude.

The results of the groundwater and spray sample analyses suggest the following minimum carbon tetrachloride removal efficiency values for the spray irrigation treatment process:

- More than 94\% (based on data for individual samples)

- Approximately 99\% (based on the average concentration delivered to the wetlands during the review period)

The results of $\mathrm{pH}$ measurements recorded for samples of the treated spray discharge are presented in Table 5.2. In all cases, the observed $\mathrm{pH}$ levels (7.01 to 8.18) were within the acceptable range (6.5 to 9.0) specified under the NPDES permit.

\subsection{Results for Well GWEX4, with Treatment by Air Stripping}

Carbon tetrachloride concentrations in the untreated groundwater produced by GWEX4 were relatively stable $(53 \mu \mathrm{g} / \mathrm{L}$ to $95 \mu \mathrm{g} / \mathrm{L})$ during the review period; however, a possible trend of gradually decreasing levels is suggested in the data of Table 5.1. Carbon tetrachloride was not detected in the effluent from the air stripping unit throughout the review period, indicating a carbon tetrachloride removal efficiency of $>99 \%$ for this process. Measured $\mathrm{pH}$ levels in all samples of the air stripper effluent (7.01 to 8.35; Table 5.2) were within the acceptable range (6.5 to 9.0$)$ specified under the NPDES permit.

\subsection{Estimated Removal of Carbon Tetrachloride from the Utica Aquifer}

The groundwater production and carbon tetrachloride concentration data presented in Tables 4.1 and 5.1, respectively, can be used to estimate the total quantity of carbon tetrachloride extracted by wells GWEX1-GWEX4 from October 29, 2004, to November 31, 2005. The results of these calculations, summarized in Table 5.3, indicate that approximately $23 \mathrm{~kg}$ ( $3.8 \mathrm{gal}$ ) of carbon tetrachloride was removed from the Utica aquifer during the review period. 
TABLE 5.3 Estimation of carbon tetrachloride removed from the Utica aquifer. ${ }^{\text {a }}$

\begin{tabular}{|c|c|c|c|c|c|c|c|c|}
\hline \multirow[b]{4}{*}{ Month } & \multicolumn{4}{|c|}{ GWEX1-GWEX3 } & \multicolumn{4}{|c|}{ GWEX4 } \\
\hline & & & \multicolumn{2}{|c|}{ Carbon Tetrachloride } & & & \multicolumn{2}{|c|}{ Carbon Tetrachloride } \\
\hline & \multicolumn{2}{|c|}{$\begin{array}{l}\text { Groundwater } \\
\text { Extracted }\end{array}$} & \multirow{2}{*}{$\begin{array}{l}\text { Concentration } \\
(\mu \mathrm{g} / \mathrm{L})\end{array}$} & \multirow{2}{*}{$\begin{array}{l}\text { Calculated } \\
\text { Amount } \\
\text { Removed } \\
(\mathrm{kg})\end{array}$} & \multicolumn{2}{|c|}{$\begin{array}{l}\text { Groundwater } \\
\text { Extracted }\end{array}$} & \multirow{2}{*}{$\begin{array}{l}\text { Concentration } \\
\qquad(\mu \mathrm{g} / \mathrm{L})\end{array}$} & \multirow{2}{*}{$\begin{array}{l}\text { Calculated } \\
\text { Amount } \\
\text { Removed } \\
(\mathrm{kg})\end{array}$} \\
\hline & (gal) & (L) & & & (gal) & (L) & & \\
\hline Oct 2004 & $-^{\mathrm{c}}$ & - & - & - & 263,520 & 997,687 & 85.5 & 0.1 \\
\hline Nov 2004 & 928,680 & $3,515,982.5$ & 115 & 0.4 & $2,687,040$ & $10,173,133$ & 85.5 & 0.9 \\
\hline Dec 2004 & $1,077,780$ & $4,080,475.1$ & 112 & 0.5 & $2,660,544$ & $10,072,820$ & 91.5 & 0.9 \\
\hline Jan 2005 & 149,100 & $564,492.6$ & 103 & 0.1 & $2,544,480$ & $9,633,401$ & 81.0 & 0.8 \\
\hline Feb 2005 & $2,051,190$ & $7,765,805.3$ & 101 & 0.8 & $2,298,240$ & $8,701,137$ & 91.0 & 0.8 \\
\hline Mar 2005 & $4,155,630$ & $15,733,215$ & 111 & 1.7 & $2,620,368$ & $9,920,713$ & 90.5 & 0.9 \\
\hline Apr 2005 & $3,059,580$ & $11,583,570$ & 101 & 1.2 & $2,397,600$ & $9,077,314$ & 89.0 & 0.8 \\
\hline May 2005 & $1,829,500$ & $6,926,487$ & 103 & 0.7 & $2,410,560$ & $9,126,380$ & 71.0 & 0.6 \\
\hline Jun 2005 & - & - & - & - & $2,332,800$ & $8,831,981$ & 67.0 & 0.6 \\
\hline Jul 2005 & - & - & - & - & $2,332,800$ & $8,831,981$ & 69.0 & 0.6 \\
\hline Aug 2005 & $1,506,200$ & 5702473.2 & 117 & 0.7 & $2,096,460$ & $7,937,198$ & 57.0 & 0.5 \\
\hline Sept 2005 & $6,749,100$ & 25552093 & 115 & 2.9 & $2,273,000$ & $8,605,578$ & 64.5 & 0.6 \\
\hline Oct 2005 & $9,008,200$ & 34105045 & 101 & 3.4 & $2,455,905$ & $9,298,056$ & 56.0 & 0.5 \\
\hline Nov 2005 & $4,097,000$ & 15511242 & 118 & 1.8 & $2,379,375$ & $9,008,314$ & 53.0 & 0.5 \\
\hline TOTAL & & & & 14.2 & & & & 9.0 \\
\hline
\end{tabular}

a Total carbon tetrachloride removed from the aquifer: $23.2 \mathrm{~kg}$.

b Concentration in untreated "mixed" samples of the combined flow from wells GWEX1-GWEX3.

c Unit not in operation. 


\section{Operation, Maintenance, and System Modifications}

\subsection{Wells GWEX1-GWEX3 and the Spray Irrigation Treatment Units}

No repairs or maintenance were required on extraction wells GWEX1-GWEX3 during the review period.

Maintenance and repairs for the spray irrigation units and the groundwater delivery system included the following:

- Periodic field inspection of the units and all operating parameters.

- Replacement (under warranty) of numerous pneumatic valves, used to selectively control the operation of the spray heads. The valves were damaged by freezing during the initial setup of the irrigation units.

- Replacement of the electronic valve actuators used to control the irrigation span drain-back system. The actuators were damaged as a result of the basin flooding that took place in May 2005.

- Repair (under warranty) of the base station remote system computer, to correct damage resulting from a lightning strike through the telephone wiring. Additional surge protection was also installed.

- Adjustment of the pump motor variable frequency drives, to reduce their sensitivity to line power quality.

- Replacement of a malfunctioning manual pipeline valve that controls the flow of groundwater to the north spray unit.

- Ongoing investigation to diagnose the cause(s) of sporadic, unexpected shutdowns of the wells and treatment units. 
Several modifications of the spray irrigation and groundwater delivery systems were made during the review period. These updates include the following:

- Replacement of the radio hardware required for remote control and monitoring of the spray irrigation units, to permit the use of governmentspecific radio frequencies.

- Redesign and reconstruction of the drain-back valve vault at the south spray irrigation site, to prevent water damage in the event of future flooding.

\subsection{Well GWEX4 and the Air Stripping Unit}

Well GWEX4 required no maintenance or repairs during the review period.

Maintenance of the shallow-tray air stripper was limited to the following:

- Periodic field inspection of the unit and all operating parameters.

- Replacement of a view port on one of the aeration trays.

- Routine cleaning of the unit after approximately one year of operation. Inspection of the unit at that time revealed minimal silting or buildup of precipitates; these were removed by pressure washing.

\subsection{Installation and Sampling of Monitoring Wells}

At the beginning of the aquifer restoration program, only three permanent monitoring wells at the Utica site could be used for the sampling of groundwater for VOCs analyses. Preexisting wells SB48, SB71, and SB72 (Figure 2.1) were constructed primarily for measurement of groundwater levels and do not penetrate the more contaminated zones of the groundwater column identified in detailed vertical-profile sampling (Argonne 2000). To improve monitoring coverage, four additional permanent monitoring wells (MW1-MW4; Figure 2.1) were installed at strategic locations along the plume migration pathway in August 2005. A 
proposed fifth monitoring well (Figure 2.2 of Argonne 2004) was not installed because of access issues.

Table 6.1 summarizes construction data for the new and preexisting monitoring wells, as well as the results of groundwater sampling and analyses for VOCs to date. No clear trends in the patterns of carbon tetrachloride levels at the monitoring wells were apparent during the review period. Well registration forms for the new monitoring wells (installed in 2005) are in Appendix A.

TABLE 6.1 Well construction data and analytical results for carbon tetrachloride in groundwater samples from the permanent monitoring wells.

\begin{tabular}{|c|c|c|c|c|c|c|c|c|}
\hline \multirow[b]{3}{*}{ Well } & \multicolumn{2}{|c|}{ Depth (ft BGL) } & \multirow{2}{*}{\multicolumn{6}{|c|}{ Carbon Tetrachloride ( $\mu \mathrm{g} / \mathrm{L})$}} \\
\hline & & \multirow{2}{*}{$\begin{array}{l}\text { Screened } \\
\text { Interval }\end{array}$} & & & & & & \\
\hline & Total & & Nov 04 & Jan 05 & Feb 05 & Mar 05 & Aug 05 & Oct 05 \\
\hline SB48 & 98.5 & $83.5-93.5$ & $N D^{a}$ & ND & ND & ND & $-b$ & ND \\
\hline SB71 & 94.2 & $84.0-94.0$ & 1.3 & 1.2 & 1.0 & ND & - & $0.3 \mathrm{~J}^{\mathrm{c}}$ \\
\hline SB72 & 122.3 & $82.6-112.6$ & $5.5-5.7^{d}$ & $4.3-6.2$ & $5.1-5.6$ & $1.9-3.4$ & - & 3.6 \\
\hline MW1 & 105.0 & $85.0-100.0$ & - & - & - & - & 38.0 & 79.0 \\
\hline MW2 & 115.0 & $90.0-110.0$ & - & - & - & - & $8.6-8.8$ & 9.3 \\
\hline MW3 & 125.0 & $100.0-120.0$ & - & - & - & - & 57.0 & 36.0 \\
\hline MW4 & 125.0 & $100.0-120.0$ & - & - & - & - & 34.0 & $33.0-34.0$ \\
\hline
\end{tabular}

a ND, not detected at a method detection limit of $0.1 \mu \mathrm{g} / \mathrm{L}$.

b Well not sampled.

c Qualifier J indicates an estimated concentration below the quantitation limit of $1 \mu \mathrm{g} / \mathrm{L}$ for the purge-and-trap method.

d Ranges of values include quality control samples.

\subsection{First-Year Operating and Maintenance Costs}

First-year operating and maintenance costs are summarized in Table 6.2. These costs include one-time expenses associated with installation of new monitoring wells. Other expenses were related to unexpected technical problems and spring flooding that necessitated modification and rebuilding of the actuator system to withstand future flooding. Costs in subsequent years are expected to be lower. 
Utica First-Year Review, October 2004-November 2005

Version 00, 12/12/05

TABLE 6.2 Summary of first-year operating and maintenance costs for the Utica restoration project.

\begin{tabular}{lr}
\hline \multicolumn{1}{c}{ Item } & Cost $(\$)$ \\
\hline & \\
General Management & 18,127 \\
Logistics Support & 64,145 \\
Remediation Monitoring & 170,880 \\
Monitoring Network Establishment & 11,707 \\
Technical Oversight & 17,727 \\
TOTAL & \\
& \\
\hline
\end{tabular}




\section{Summary}

A combined total of approximately 66.4 million gallons of contaminated groundwater was extracted and treated during the first 13 months of operation of the aquifer restoration systems at Utica. Approximately 52\% of the total volume treated (106 acre-feet) was used to supplement the natural water entering the North Lake Basin Wildlife Management Area.

Groundwater modeling studies performed by Argonne during the development of the aquifer restoration approach for Utica (Argonne 2000) indicated that, on average, the extraction of approximately 97 million gallons of groundwater per year would be required to achieve cleanup of the aquifer in approximately 10-15 years. The total actual groundwater produced during the review period represents approximately $68 \%$ of this average annual target.

Sampling and analysis of the effluent water from the air stripping and spray irrigation treatment units indicated that these systems functioned at a minimum efficiency of $94 \%$ during the review period. Carbon tetrachloride concentrations in all discharges of treated water at the site were below the permitted maximum target $(44.2 \mu \mathrm{g} / \mathrm{L})$ by roughly an order of magnitude.

Calculations based on the volumes and measured carbon tetrachloride concentrations of the groundwater extracted during the review period indicated that approximately $23 \mathrm{~kg}$ ( $3.8 \mathrm{gal}$ ) of carbon tetrachloride was removed from the Utica aquifer.

The costs incurred by Argonne for operating and maintenance of the aquifer restoration effort at Utica during the review period were approximately $\$ 283,000$. 


\section{References}

Argonne, 2000, Final Report: Stage I Investigations of the Agricultural/Environmental Enhancement Pilot Program, Utica, Nebraska, prepared for the Commodity Credit Corporation, U.S. Department of Agriculture, by Argonne National Laboratory, Argonne, Illinois, January.

Argonne, 2004, Final Monitoring Plan for the Utica Aquifer-North Lake Basin Restoration Project at Utica, Nebraska, ANL/ER/TR-04/006, prepared for the Commodity Credit Corporation, U.S. Department of Agriculture, by Argonne National Laboratory, Argonne, Illinois, November. 
Utica First-Year Review, October 2004-November 2005

\section{Appendix A:}

\section{Well Registration Forms}


Utica First-Year Review, October 2004-November 2005

Version 00, 12/12/05

A-2

\section{GWEX-1}




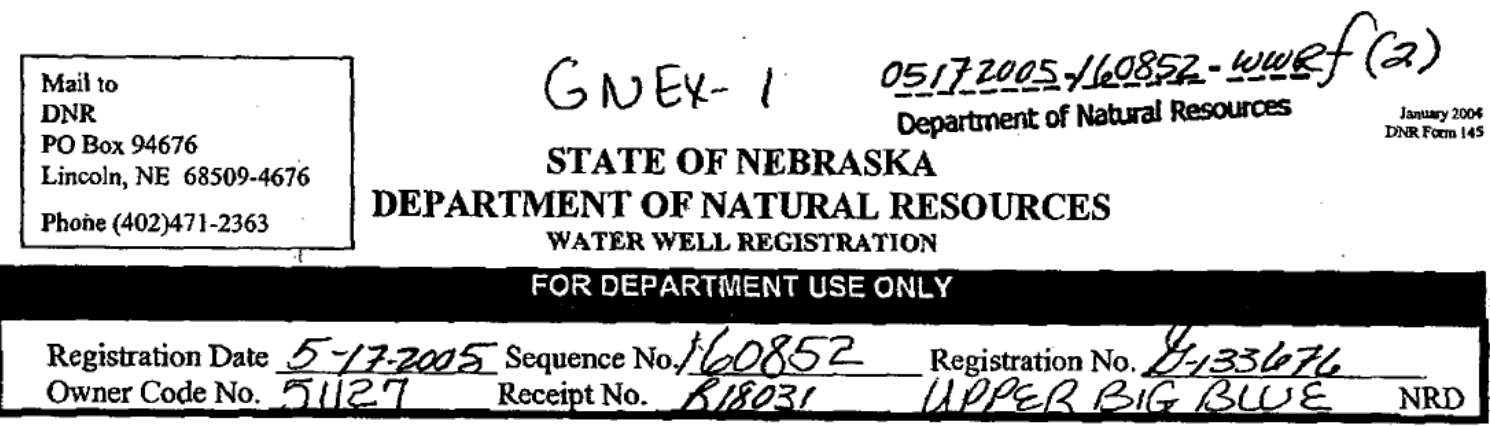

1. a. Well Owner's First Name

b. Company Name USDA / FSA

c. Correspondent Name Address Mail Stop 4725, Room 4725, South Building City Waschington

Last Name 2. a. Contractor's License No 19193 Contractor's Name_Michael Magnin
Contractor's Email Address mmagnin@boartlongyear.com

b. Drilling Firm Name Boart Longyear Address P.O. Box 355 City Little Falls Drilling Firm's Email Address sthalacker@boartlongyear.com State MN

3. a. Well location NW/1/4 of the $N_{1 / 4}^{1 / 4}$ of Section 29 , Township 11 North, Range 1 E $\left.\square\right]$ w

b. Natural Resources District Upper Big Blue

c. The well is 600 feet from the $(\mathrm{N}, \mathrm{S} \square)$ section line and 190 or Latitude Degree Minute (circle one) Attention Longitude Degree Minute Second

d. Street address and subdivision, if applicable Block

e. Location of water use, if applicable (give legal descriptions) $\leq-29$

g. Well reference letter(s), if applicable $6 N E X-1$ acres. HHSS PWSID

4. Permits

Management Area Permit Number G-097200

Geothermal Permit Number

Municipal Permit Number

Well Spacing Permit Number HHSS

5. Purpose of well (indicate one) _ Dquaculture $\quad$ Commercial/Industrial Dewatering (over 90 days) Domestic Gound Heat Exchanger Goundwater Source Heat Pump Irrigation Public Water Supply (withour spexing) Surface Water Permit Number Industrial Permit Number

Transfer Out-Of-State Permit Number Conduct Permit Number Other Permit Number NDEQ

6. Wells in a Series.

a. Is this well a part of a series? Yes go to part b of this section go to part 7 of this application

b. If one or more of the wells in the series is currently registered, give the well registration number G-097200

c. How many wells in the series are you registering at this time? 2

7. Replacement and abandoned well information.

a. Is this well a replacement well? $\mathrm{Y}$ Yes

b. Registration number of abandoned well____ If not registered, date abandoned well was constructed $(\mathrm{m}) \_$_ $/(\mathrm{d}$ __ $/(\mathrm{y})$

c. Replacement well is ____ feet from abandoned well. d. Abandoned well last operated (m)_____

e. Original well pump column size ____ inches. f. Completion of original well abandonment on $(\mathrm{m})$ _ I $/ \mathrm{d}$

g. Location of water use of abandoned well KECEEVED 
8. Pump Information.

a. Is pump installed at this time $\square$ Nos

Is pump installed by well owner in section 1 ? $\square$ Yes $\square$ No is pump installed by contractor in section 2 ? $\square$ Yes $\square$ No

If pump installed by pump installer, please fill out license number below

b. Pump Installer's License No. Pump Installer's Name

Pump Installer's Emai] Address

Pump Installer's Fim Name.

Pump installer's Firm Address

City State Zip Telephone

Pump Installer's Firm Email Address

c. Pumping rate ___ gallons per minute ___ Measured _ Estimated

d. Drop pipe diameter_inches e. Length of drop pipe

f. Pumping equipment installed $(m) \_/ a-f(v) \quad$ g. Pump Brand

h. This well is designed and constructed to pump less than $50 \mathrm{gpm} X$ Tes No

9. Well Construction Information.
a. Total well depth 132.0 feet.
c. Pumping water level feet.
b. Static water level 82.0
feet.
c. Well Construction completed (month) 5
d. Well Construction began (month) $5 /$ (day) $18 /$ (yar 2004
g. Casing and Screen Joints are $22 /$ (year_ 2004
f. Bore hole diameter in inches Top 16.00 Bottom 16.00

g. Casing and Scren Joins are Welded Lether

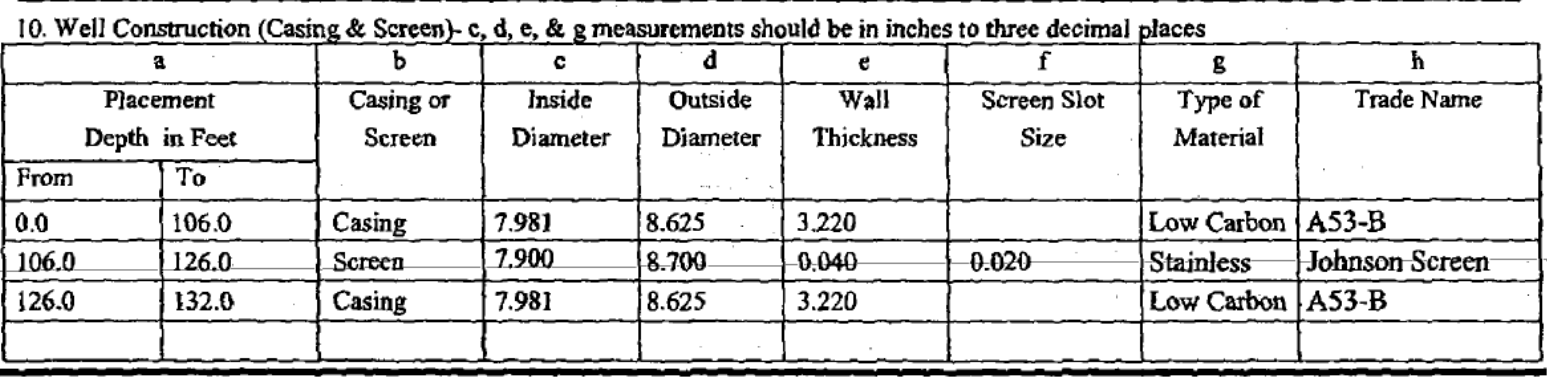

11. Grout and Gravel Pack

\begin{tabular}{|l|l|l|l|}
\hline \multicolumn{2}{|c|}{ Placement Depth in Feet } & \multicolumn{1}{|c|}{$\begin{array}{c}\text { Grout or } \\
\text { Gravel Pack }\end{array}$} \\
\hline From & To & Material Description \\
\hline 0.0 & 94.0 & Grout & Neat Cement \\
\hline 94.0 & 97.0 & Bentonite & Baroid 3/8" Chips \\
\hline 97.0 & 132.0 & Gravel Pack & $12 / 20$ Sand \\
\hline & & & \\
\hline
\end{tabular}

12. Geologic Materials Logged

Depth in Feet Description

From To

$\underline{0.0 \quad 132.0}$ Glacial Drift

Depth in Feet Description

From To

-

$\sim$

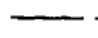

$-$

-

(Additional sheets may be submitted)

13. I am familiar with the information submitted on this registration, and to the best of my knowledge it is true.

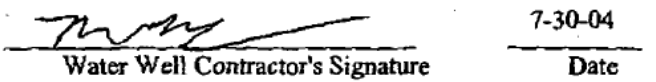

Well Owner's Signature

Date if Contractor is unknown or Deceased 


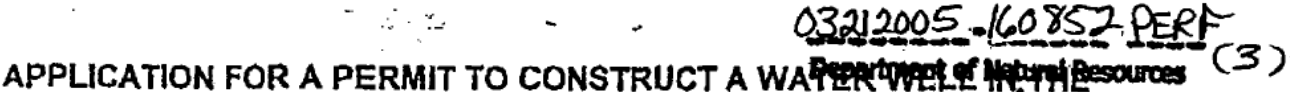 UPPER BIG BLUE NATURAL RESOURCES DISTRICT}

1. TYPE OF PERMTT REQUESTED: (Check appropriate kem(s)

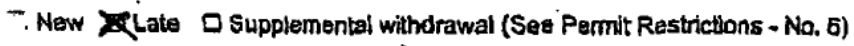
$51127)^{15}$

Is this application for a series of wells? YES. NO. If YES, How many wells? 2

\begin{tabular}{|c|c|}
\hline $\begin{array}{l}\text { NRD USE ONLY } \\
\text { PERMIT No. UBA-1- }\end{array}$ & $3484 A$ \\
\hline DAYE RECENED & $3-2-05$ \\
\hline
\end{tabular}

2. NAME AND ADDRESS OF LANDOWNER: USDA/FSA

Mail Stop 4725, $\operatorname{Rm} 4725$, South Building 1400 Independence Ave. SW; Washington, DC

Phone ( 202$) 720$
3. NAME AND AODRESS OF WELL DRILLER: Boart-Longyear Company

\begin{tabular}{l}
\hline 101 Alderson Street \\
\hline Schofield, WI 54476 \\
Phone ( 800 ) $236 \quad 4983$ \\
\hline
\end{tabular}

4. PURPOSED USE OF WELL: (Check one) DDomestic Gindustrial Gintigation DLivestock GPublic Water Supply Wher(specify) Groundwater Extraction

5. IOENTIFY THE LOCATION OF THE PROPOSED WELL: . (See Permit Regtriction's - Nos. 3 \& 4) Section_29 Township 11 North، Range 1 Eastawask Seward . County. State Registration No. (Required for replacament well and late or suppiemental permits).

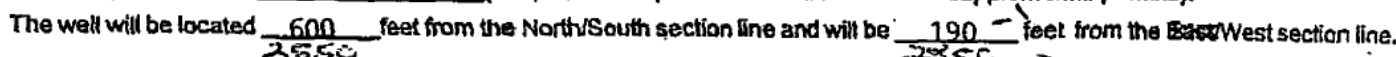

6. REPLACEMENT AND ABANDONED INFORMATION: (See Permlt Restrictions - No. 3) - 3 Will this well replace a well that is or will be permanently abandoned? OYES WNO.

Date that the originat well was last operated on 20

The replacement well will be feet from the original well. Will the replacemient well provide water to the same tract of land as the original well? DYES DNO.

7. WELL AND LAND APPLICATION SKETCH:

The box at the right represents one square mile; (1 section). Indicate with an " $X$ ", the proposed location of the well(s), outine and cross-hatch the proposed water use area.

8. IRRIGATION OR OTHER LAND APPLCATON OF WATER: How many acres will this well apply water to? Less than 100 Type of irrigation (water distribution) system is proposed? DCenter plvot DGated pipe Wother(specify) Stationary 3 Span

9. PREVIOUS IRRIGATION OR OTHER LAND APPLICATION: Are any of the acres identhed in question 8 served by another well now? DYES MNO. If YES. How many acres? What is the current distribution system? aCenter pivot DGated pipe Dother(specify)

10. GROUND WATER TRANSFER: (See Permit Restrictions - No. 5) Is the proposed well to be used to transfer water outside of the legal description listed above? YES I NO.

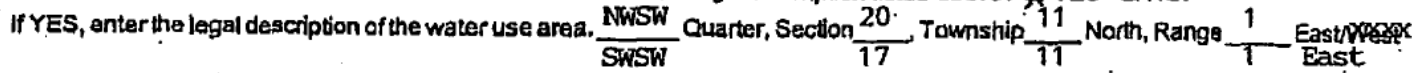

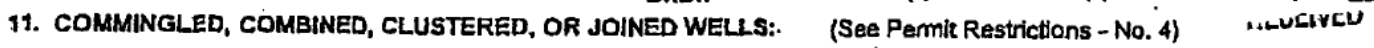
Will the proposed well be connected to another well(s) or be used to supplement an exlsing water use from another well(s)? 口NO. IfYES, Jist the State Registration No(s). of other well(s) $\mathrm{G}-097200 \mathrm{~A}$ HILP 21200 DEPARTMERYOF

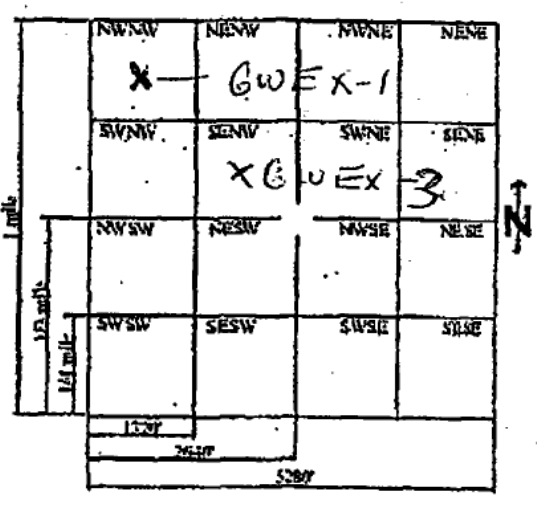



gallons per minute. Estimated total well depth: Triches. Pump column diamater: 2

13. ANNUAL WITHRRAWAL: (See Pemit Restrictions - No. 6)

Is the total annual ground water withdrawal of all well(s) on this parcel of land estimated to bo five hundred (500) acre feet or more? $\square$ YES RNO

If the existing well(s) on this parcal of land currently wifhdraw five hundred (500) acre feet or more annually, will the proposed well increase the total ground water wilthdrawal by two hundred and fifty $(250)$ acre feet or more? DYES 6 NO

14. LANDOWNER CERTIFICATION: Please read permit restrictlons listed below.

I, hereby. certify that I am famlliar with the Information contained in this application and, that to the best of my knowledge and beliet, the information is complete and aceurate. I understand and will comply with the permit restrictions and the District's rules and regulations related to the construction and gperation of this well.

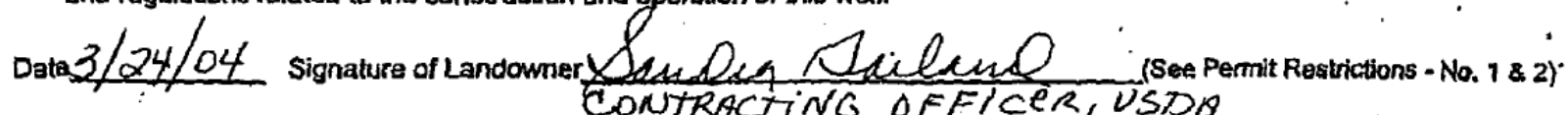
This form must bo completed in full and be accompanled by a non-refundable $\$ 50.60$ fiking fee ( $\$ 250.00$ for a late permit) payable to the Upper Big Blue NRD, 105 Lincoin Avenue, York, Nebraska 68467. An incomplete application will be returned for correction. A raturned application must be resubmitted within 30 days or the filing foe is forfeited.

\section{PERMIT RESTRICTIONS}

1. This application must be signed by the landowner, his/her power of attorney or be accompanied by a notarized statement, signed by the landowner, authorizing the another person's signature.

2. This permit shall remain in force for one (1) year from the date approved.

3. If the well authorized by this permit has a capacity of more than fity (50) gallons per minute, it must be constructed at least one thousand ( 1000 ) feet from ariy existing well with a capacity of more than fifty (50) gallons per minute that is under different ownership. If a well that is less than one thousand $(1000)$ feet from a well under separate ownership is being replaced, the replacement well may not be more than fifty $(5,0)$ feet closer to the well under separate ownership than the one it is replading.

4. When water wells are commingled, combined, clustered, or joined and have a combined total capacity of more than fifty - (50) gallons per minute, each water well shatl comply with well spacing as provided in Restriction No. 3.

5. A well shall not be used to transfer ground water to a government survey saction that is not adjacent to the tract of land in which the well is located. Transfers of ground water from the tract on which the well is located shall be limited to an acreage equal to the acreage in that tract unless such transfers occurred pritor to July 1, 1990.

6. If the total proposed annual ground water withdrawal from this parcel of land exceeds five hundred (500) acre feet (163 million gallons) or if existing well(s) currently withdraw five hundred (500) acre feet or more and the proposed weil will increase the total withdrawal by two hundred and fity (250) acre feet (81.5 million gallons) or more, a hydrologic avaluation must be submitted with this application in accordance with District Rilie 5, Ch. 5 .

7. All wells permitted by the District on or after March 1, 2004 must be equipped with a flow meter prior to operation.

Ground Water Management Area rules and regulations are-subject to change. A copy of District Rule 5 is available upon request. Prior to construction or operation, the permittee should contact the NRD office if he or she has any questions about the rules and regulations.

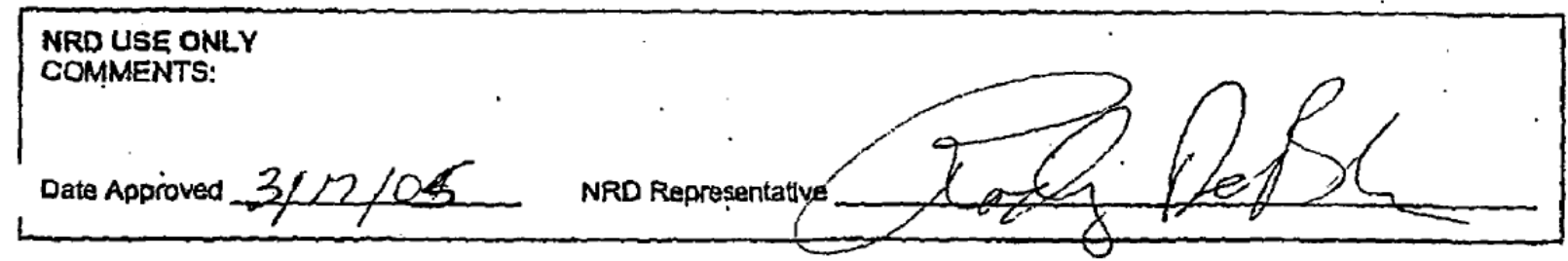

March 2004 


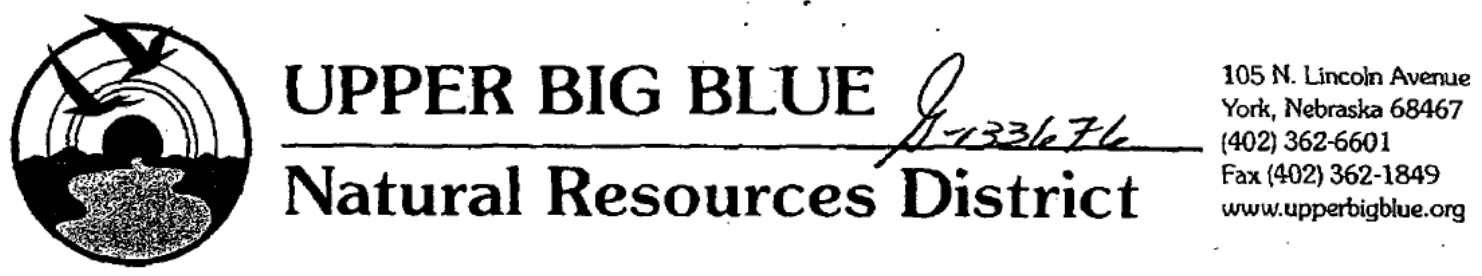

March 18, 2005

USDA/FSA

Mail Stop 4725

Room 4725 - South Building

1400 Independence Avenue

Washington, DC 20024

Subject: Late Recovery Wells Permit

Dear Sirs:

The NRD has approved the enclosed late well permit for the series of two wells, GWEX-1 and GWEX-3, located in Section 29-T11N-RIE, Seward County of the Upper Big Blue Natural Resources District Groundwater Management Area. It has been approved subject to all the restrictions listed on the permit and subject to the Management Area rules and regulations.

We will forward a copy of the well permit to the Nebraska Department of Natural Resources. If you have any questions feel free to call me at the NRD.

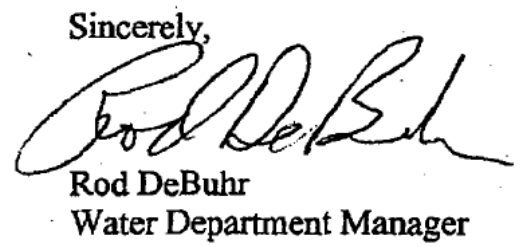

:Ish

Copy - Scott Thalacker, Boart-Longyear, Little Falls, MN

Department of Natural Resources

File

situlaticis 
Utica First-Year Review, October 2004-November 2005

Version 00, 12/12/05

A-8

\section{GWEX-2}




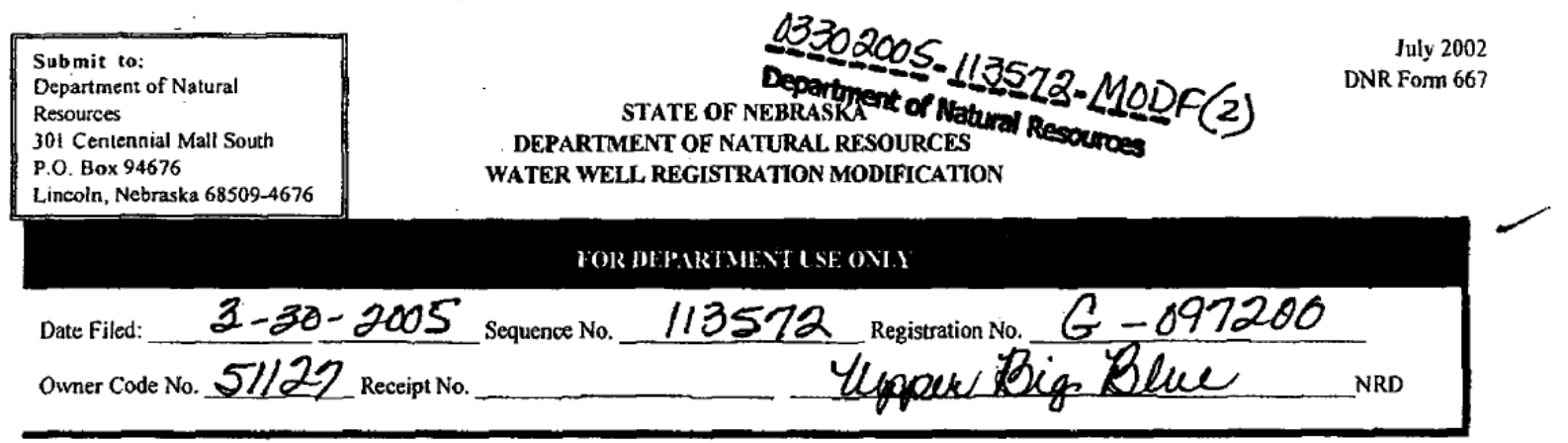

1. Well Owner(Required)_USDA/FSA

Work Telephone Number $(202720-5104$

Address Mail Stop 4725, Rm 4725, South Building; 1400 Independence Ave., SW

City Washington, () $\quad$ State_D.C. Zip Code_20250 +0513

2. Contractor(Required) TCW Construction, Inc.

Telephone Number (402) 475-5030

Address $141 \mathrm{M}$ Street $\quad$ Pump Installer License No. 39448

City Lincoln State_NE_Zip Code__68508

3. Water Well Registration No.

G-097200

$(G N E-2)$

WENTIFY WHAT NEEDS TO BE CORRECTED:_Change use of well to recovery.

4. LOCATION OF WELL (Information in ITEMS 4A and 4B are required)

LIST LEGAL:

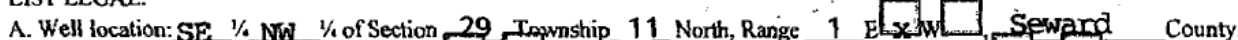

B. The well is 1350 feet from the (N section line and 3400 feet from the $\left(\mathrm{EL} W L_{4}\right)$ section line.

5. LOCATION OF WELL

LIST LEGAL CORRECT LEGAL AND/OR FOOTAGE:

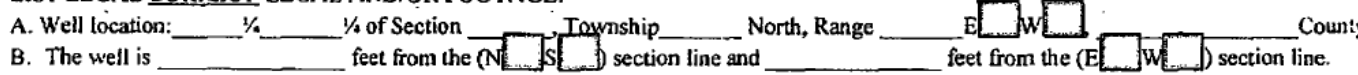

C. Latitude Degree:____ Minute: _______ Second:

D. Longitude Degree: ___ Minute: _—_ Second:

F. Block Lot

6. Number of acres irrigated:

A. Location of water use(given legal description)

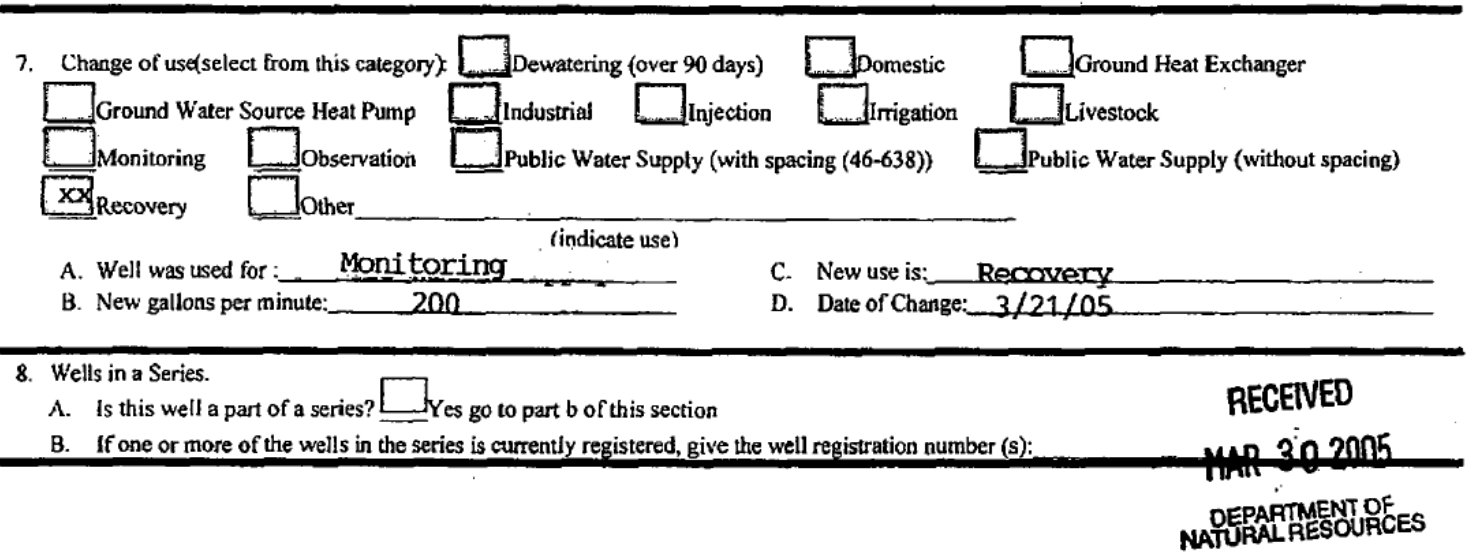




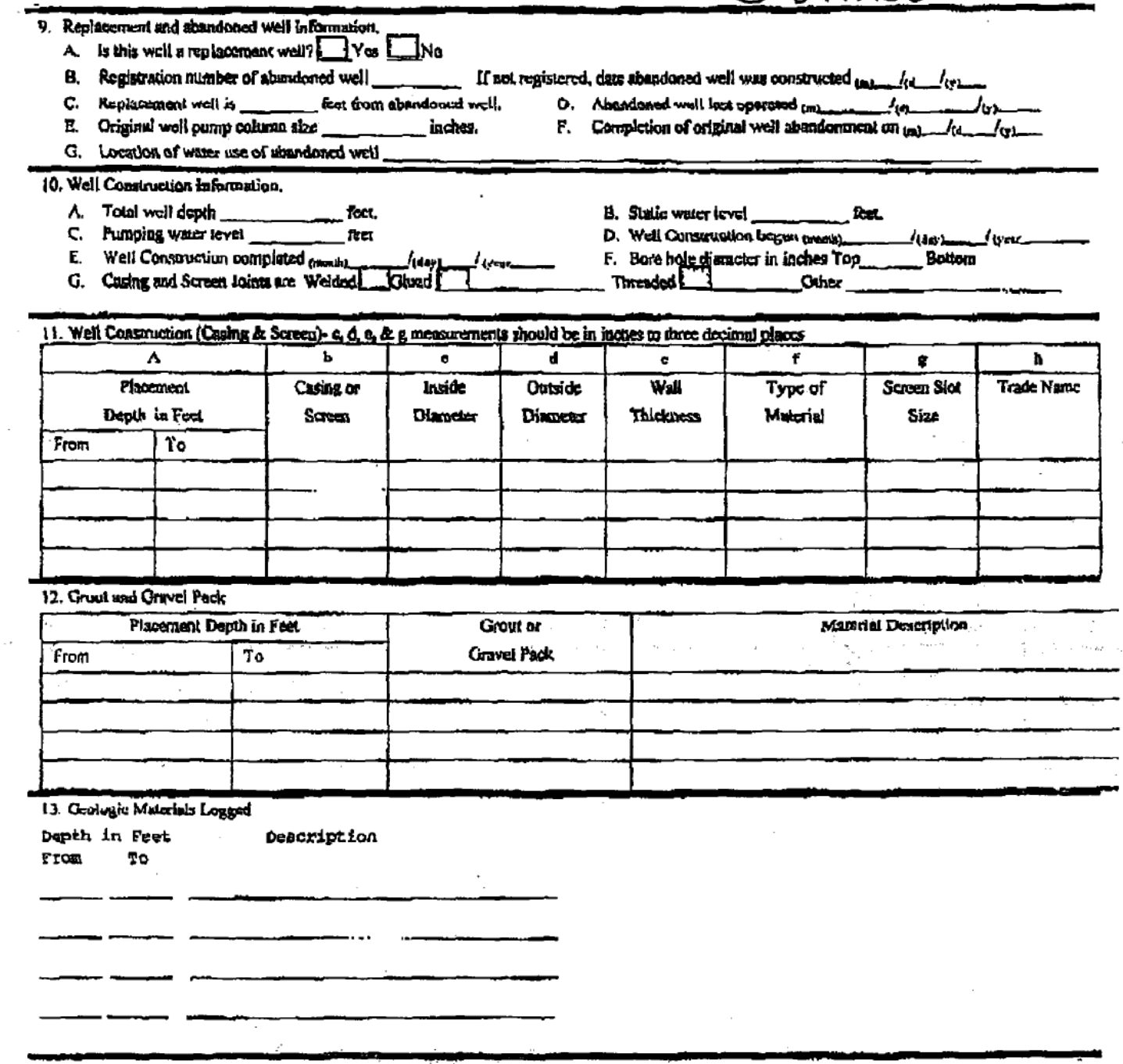

24. REOUIRED: state Resson for Change: Pell is now used to extract contaminated grouniwater

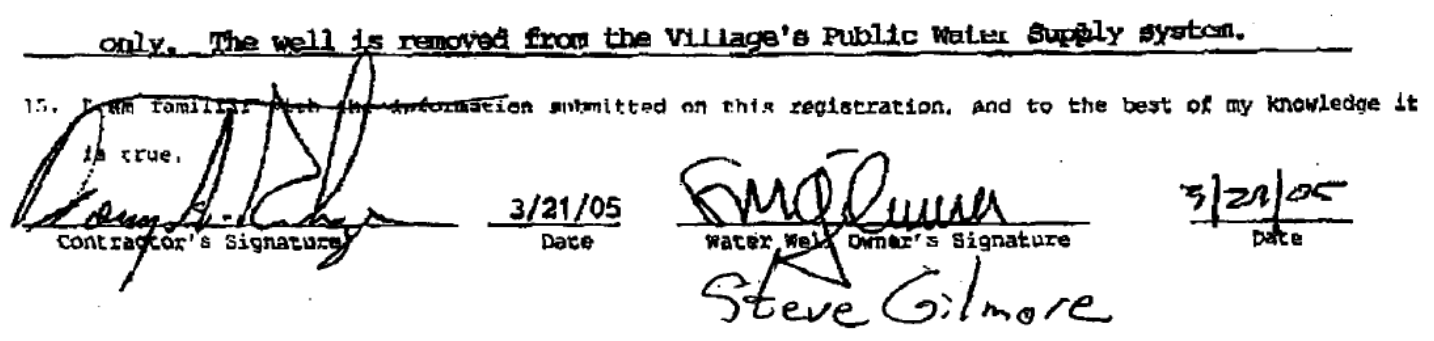


03/29/2805 12:41 2027284619

UISDA FSA CEPD

PAGE 05/05

$03 / 23 / 2005$ 18:47 FAX 4024755048

TCW CONSTRUCTION

DO0 004/004

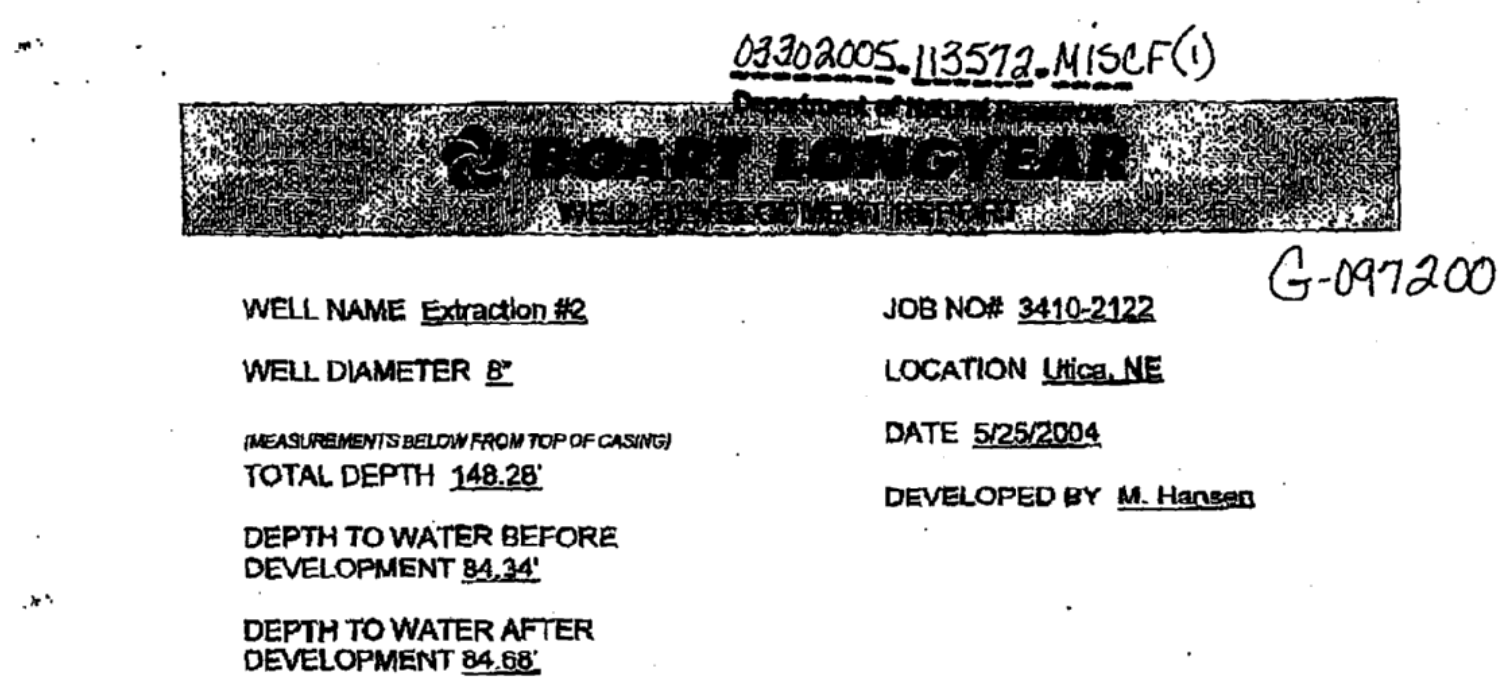

DESCRIPTION OF DEVELOPMENT METHOD

(Chear One)

[] SUROED WIBNILER \& BAILED

$\square$ SURGED WIBAILER \& PUMPED

口 SURGED WIBLOCK \& BALEO

RECENED

$\triangle$ SURGED WIBLOCK \& PUNPED

MAR 302005

L OTHER

NATURARTMESTIOF

CAN THIS WEU, BE PURGEO DRYP $\square$ YES $\triangle$ NO

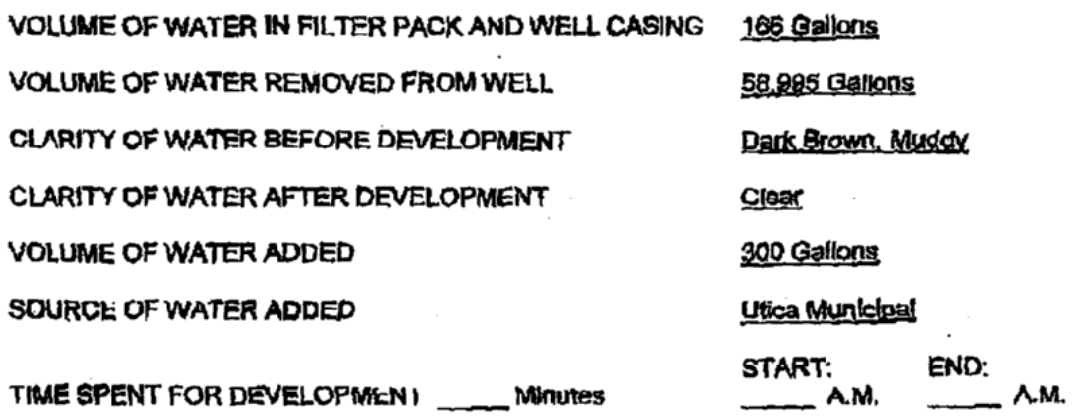

COMMENTS:

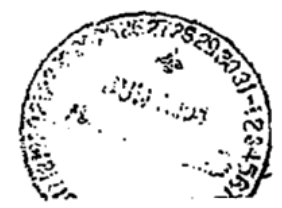



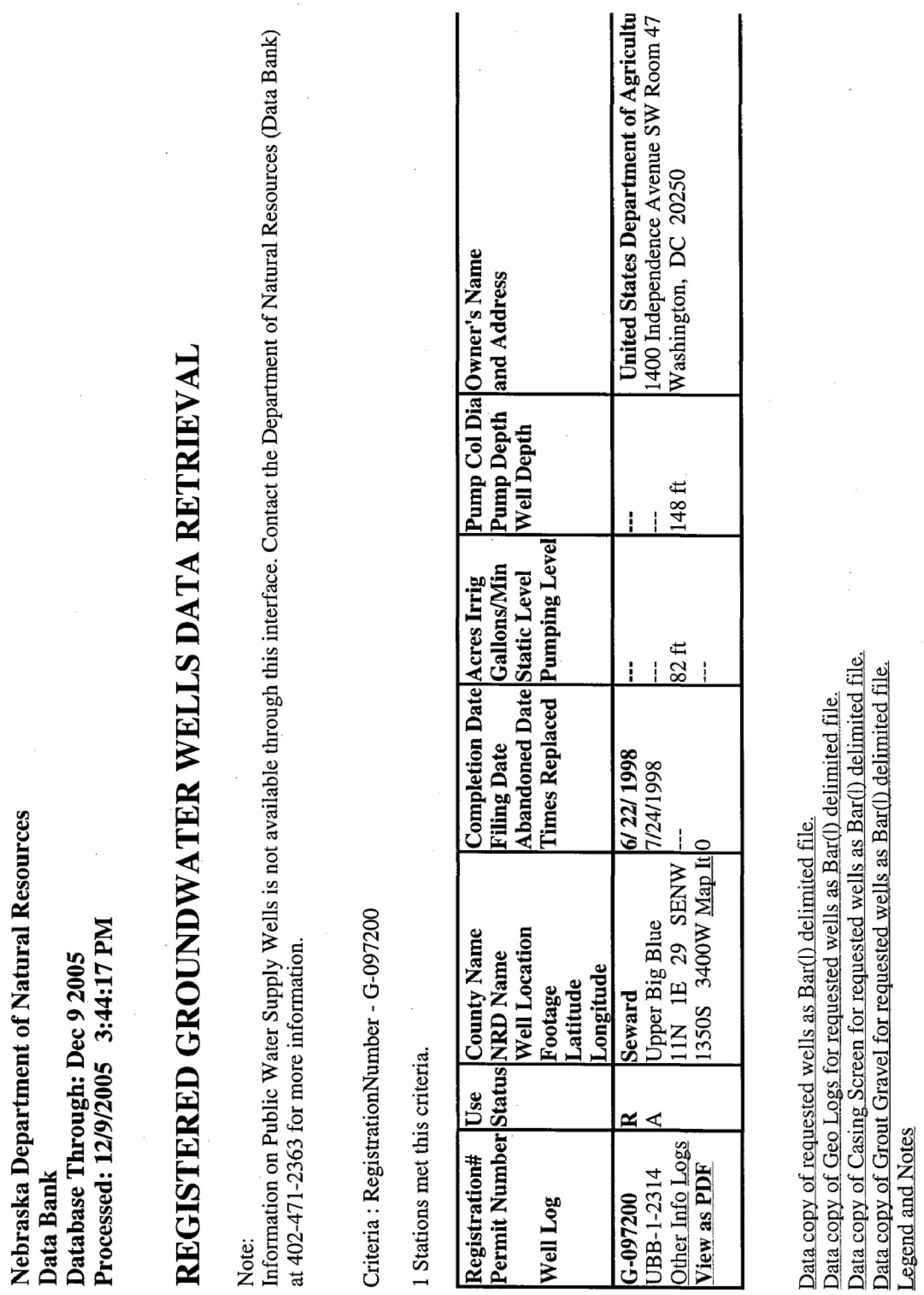
Utica First-Year Review, October 2004-November 2005

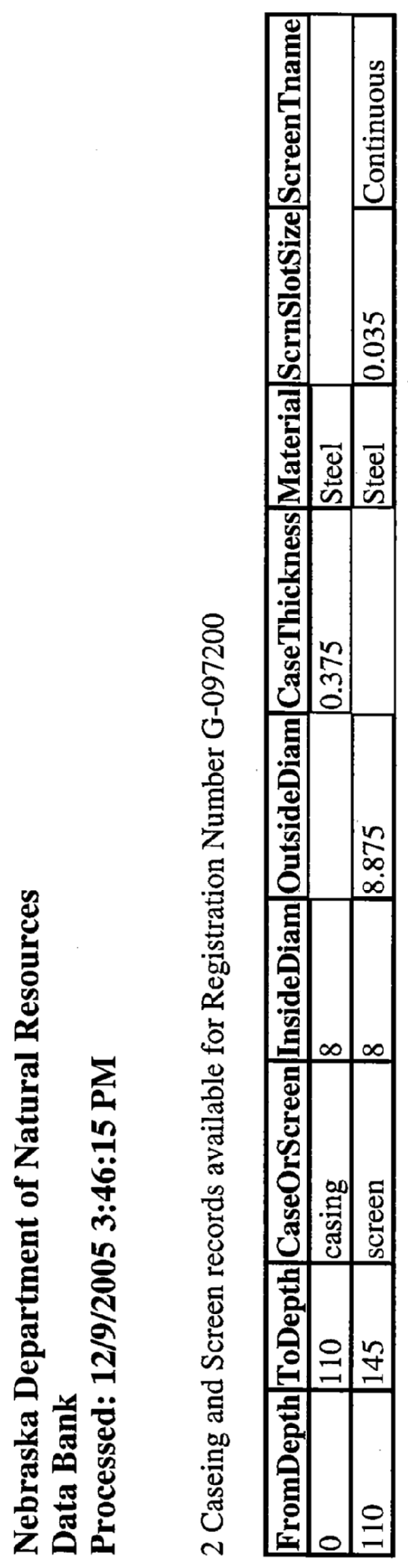


Nebraska Department of Natural Resources

Data Bank

Processed: 12/9/2005 3:47:01 PM

3 Grout Gravel information available for Registration Number G-097200

\begin{tabular}{|l|l|l|l|}
\hline FromDepth & ToDepth & GroutOrGravel & Material \\
\hline 4 & 102 & grout & Bentonite Neat Cement \\
\hline 102 & 106.8 & grout & Bentonite Chips \\
\hline 106.8 & 148.3 & gravel & \\
\hline
\end{tabular}


Nebraska Department of Natural Resources

Data Bank

Processed: 12/9/2005 3:48:11 PM

13 Logs Available for Registration Number G-097200, Well ID 113572

\begin{tabular}{|l|l|l|}
\hline \multicolumn{2}{|c|}{ Depth } & \\
\cline { 1 - 2 } From & To & \\
\hline 0 & 4 & Dark Brown Organics \\
\hline 4 & 40 & Brown Silty Clay \\
\hline 40 & 45 & Sand \& Gravel \\
\hline 45 & 50 & Silty Sand with Some Gravel \\
\hline 50 & 86 & Sand, Fine, Silty with Trace Clay \& Manganese \\
\hline 86 & 101 & Sand \& Gravel \\
\hline 102 & 108 & Sand, Fine \\
\hline 108 & 110 & Sand \& Gravel \\
\hline 110 & 132 & Sand, Fine \\
\hline 132 & 136 & Sand, Medium \\
\hline 136 & 148 & Sand, Fine \\
\hline 148 & 150 & Sand \& Gray Clay \\
\hline 150 & 152 & Gray Clay \\
\hline
\end{tabular}




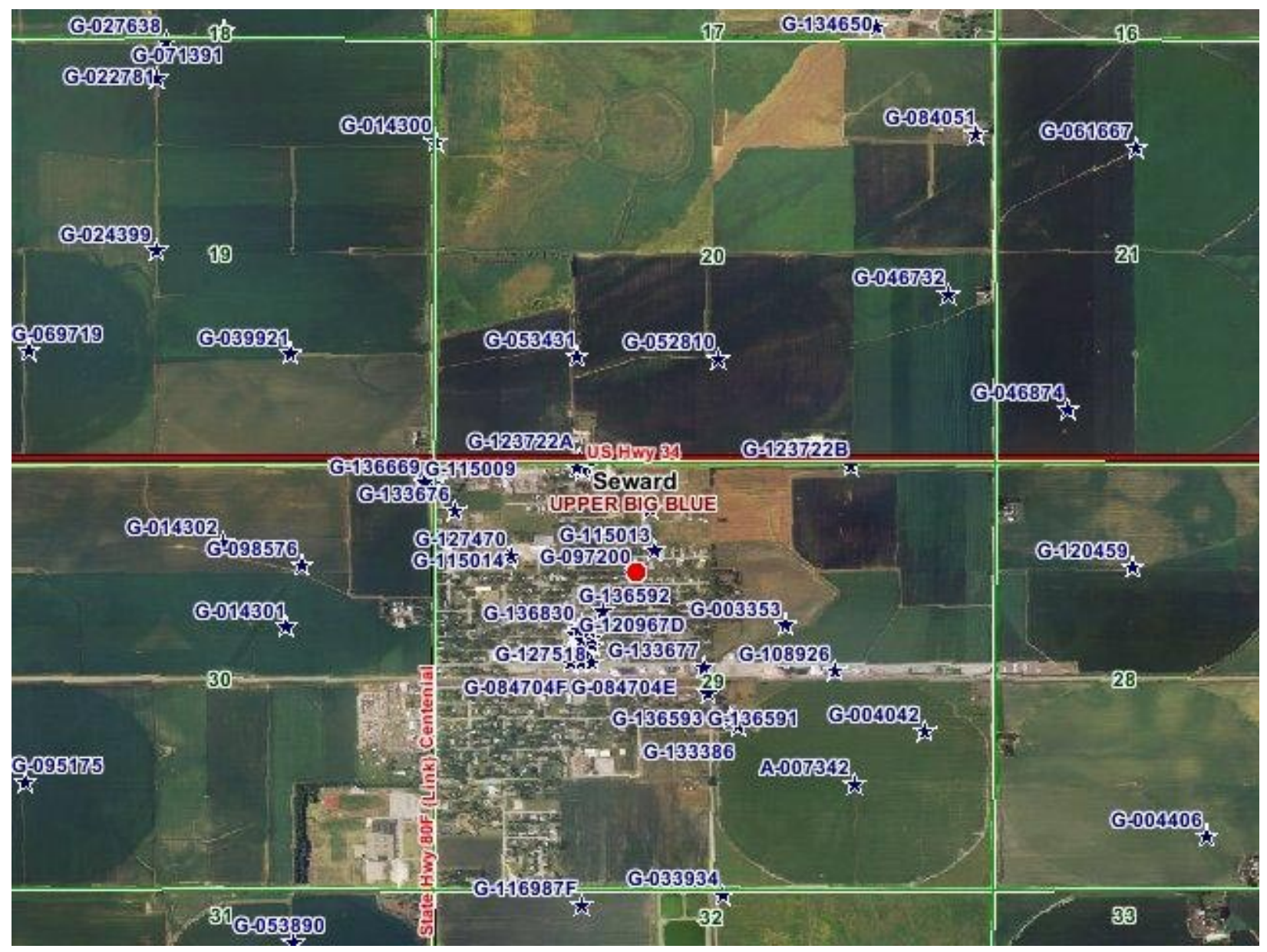


Utica First-Year Review, October 2004-November 2005

Version 00, 12/12/05

\section{GWEX-3}




\begin{tabular}{|l|}
\hline Mail to \\
DNR \\
PO Box 94676 \\
Lincoln, NE 68509-4676 \\
Phone (402)471-2363 \\
\hline
\end{tabular}

\section{GNEX-3 \\ STATE OF NEBRASKA ${ }^{\text {pepartment of Natural Resources }}$ \\ $05 / 72005-160853-$ w ase $(2)$ DEPARTMENT OF NATURAL RESOURCES WATER WELL REGISTRATION}

\section{FOR DEPARTMENT USE ONLY}

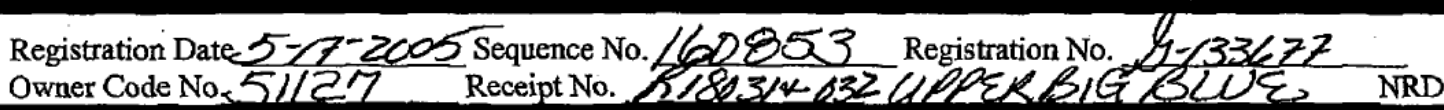

1. a. Well Owner's First Name

b. Company Name USDA / FSA

c. Correspondent Name Address Mail Stop 4725 , Room 4725, South Building

Last Name City Waschington State DC

Attention Zip $20024 \quad$ Telepbone Contractor's Name Michael Magnin

2. a. Contractor's License No 19193 Contractor's Name

b. Drilling Firm Name Boart Longyear

Address P.O. Box 355

City Little Falls State MN Zip 56345 Telephone 320-632-6552

Drilling Firm's Email Address sthalacker@boartlongyear.com

3. a. Well location $\underline{S E} 1 / 4$ of the $N W_{1 / 4}$ of Section 29 Township 11 North, Range 1 E $[\mathrm{W} \square$ Seward County.

b. Natural Resources District Upper Big Blue

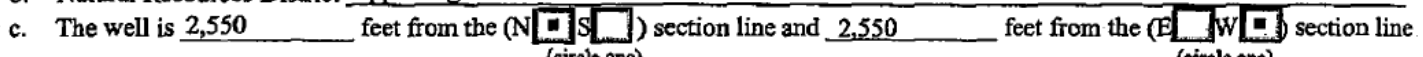
or Latitude Degree_____ Minute____ Second Longitude Degree__ Minute___ Second

d. Street address and subdivision, if applicable Block

e. Location of water use, if applicable (give legal descriptions)
f. If for irrigation, the land to be irrigated is $510 \mathrm{O}$

g. Well reference letter(s), if applicable $G N E X-3$ acres.

4. Permits

Management Area Permit Number G-097200

Geothermal Permit Number

Municipal Permit Number

Well Spacing Permit Number HHSS

HHSS PWSID

5. Purpose of well (indicate one) DAquaculture Dewatering (over 90 days)

Domestic $\square$ Ground Heat Exchanger Groundwater Source Heat Pump Injection

Monitoring Livestock Oubservation Water Supply (with spacing (46-638)

Tublic Water Supply (wibout spacing)

Surface Water Permit Number

Industrial Permit Number

Transfer Out-Of-State Permit Number

Conduct Permit Number

Other Permit Number

NDEQ

(indicate use)

6. Wells in a Series.

a. Is this well a part of a series? Yes go to part b of this section

b. If one or more of the welis in the series is currently registered, give the well registration number $\mathrm{G}-097200$.

c. How many wells in the series are you registering at this time? 2

7. Replacement and abandoned well information.

a. Is this well a replacement well? Yes

b. Registration number of abandoned well

c. Replacement well is feet from abandoned well. d. Abandoned well last operated (m)

e. Original well pump column size

g. Location of water use of abandoned weil inches. $1(0)$ (a) $I^{\prime}(x)$ HECEWEO 
8. Pump Information.

a. Is pump installed at this time $\square$ Yes No

Is pump installed by well owner in section 1 ? Yes No Is pump installed by contractor in section 2? No

If pump installed by pump installer, please fill out license number below

b. Pump Installer's License No.

Pump Installer's Name

Pump Installer's Email Address

Pump Installer's Firm Name

Pump Installer's Firm Address

City State Zip

Telephone

Pump Installer's Firm Email Address

c. Pumping rate gallons per minute $\square$ Measured $\square$ Estimated

d. Drop pipe diameter inches e. Length of drop pipe

f. Pumping equipment installed $(m) \_I_{(\alpha} /(v) \quad$ g. Pump Brand

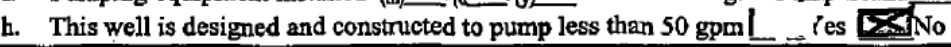

9. Well Construction Information.

a. Total well depth 146.0 feet.

c. Pumping water level

e. Well Construction completed (montb) $5 /$ (day) $25 /$ (year 2004

e. Well Construction completed (month) 5 /(day) $25 /$ (year_ 2004

Static water level 82.0

feet.

g. Casing and Screen Joints are Welded $[$ Glued

d. Well Construction began (monti) 5

(day) $22 /$ (vear 2004

Threaded Other

10. Well Construction (Casing \& Screen)- c, d, e, \& g measurements should be in inches to three decimal places

\begin{tabular}{|l|l|l|l|l|l|l|l|l|}
\hline \multicolumn{2}{|c|}{$\begin{array}{c}\text { Placement } \\
\text { Depth in Feet }\end{array}$} & $\begin{array}{c}\text { Casing or } \\
\text { Screen }\end{array}$ & $\begin{array}{c}\text { Inside } \\
\text { Diameter }\end{array}$ & $\begin{array}{c}\text { Outside } \\
\text { Diameter }\end{array}$ & $\begin{array}{c}\text { Wall } \\
\text { Thickness }\end{array}$ & $\begin{array}{c}\text { Screen Slot } \\
\text { Size }\end{array}$ & $\begin{array}{c}\text { Type of } \\
\text { Material }\end{array}$ & Trade Name \\
\hline From & To & & & & & & \\
\hline 0.0 & 105.0 & Casing & 7.981 & 8.625 & 3.220 & & Low Carbon & A53-B \\
\hline 105.0 & 140.0 & Screen & 7.900 & 8.700 & 0.040 & 0.020 & Stainless & Johnson Screen \\
\hline 140.0 & 146.0 & Casing & 7.981 & 8.625 & 3.220 & & Low Carbon & A53-B \\
\hline & & & & & & & & \\
\hline
\end{tabular}

11. Grout and Gravel Pack

\begin{tabular}{|l|l|l|l|}
\hline \multicolumn{2}{|c|}{ Placement Depth in Feet } & \multicolumn{1}{c|}{$\begin{array}{c}\text { Grout or } \\
\text { Gravel Pack }\end{array}$} & \multicolumn{1}{|c|}{ Material Description } \\
\hline From & To & \multicolumn{1}{|c|}{ Neat Cement } \\
\hline 0.0 & 97.0 & Grout & Baroid 3/8" Chips \\
\hline 97.0 & 101.0 & Bentonite & $12 / 20$ Sand \\
\hline 101.0 & 146.0 & Gravel Pack & \\
\hline & & & \\
\hline
\end{tabular}

12. Geologic Materials Logged

Depth in Feet Description

From To

$\underline{0.0} \quad \underline{146.0}$ Glacial Drift

Depth in Feet Description

(asciption

-

(Additional sheets may be submitted)

13. I am familiar with the information submitted on this registration, and to the best of my knowledge it is true.

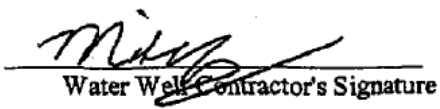

$$
\frac{7-30-04}{\text { Date }}
$$

Well Owner's Signature

Date if Contractor is unknown or Deceased 


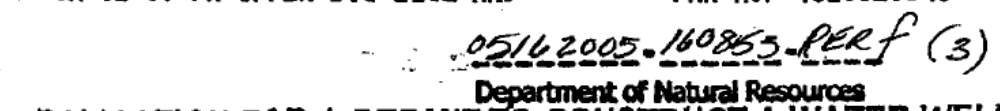

\section{APPLICATION FOR A PERMIT TO CONSTRUCT A WATER WEL
UPPER BIG BLUE NATURAL RESOURCES DISTRICT}

1. TYPE OF PERMIT REQUESTEO: (Check appropriate item(s)

-. New ZLate 0 Supplemental withdrawal (See Permit Restrictions - No. 6) Is this application for a series of wells? Y YES. NO. IfYES, How many wells? 2

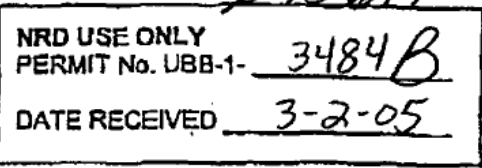

2. NAME AND ADDRESS OF LANDOWNER: USDA/FSA Mail Stop 4725, Rm 4725, South Building 1400 Independence Ave. SW; Washington, DC

Phone $202,220=5104$ 20024
3. NAME AND ADDRESS OF WELI DRILLER: Boart-Iongyear Company

\begin{tabular}{l}
101 Alderson Street \\
\hline Schofield, Wr 54476 \\
\hline
\end{tabular}

Phone ( 800 ) $236=4983$

4. PURPOSED USE OF WELL: (Check one)

QDomestic Dindustrial alrigation QLivestock 口Public Water Supply Wther(specify) Groundwater Extraction

5. IDENTIFY THE LOCAMION OF THE PROPOSED WELL: . (See Permit Restriction' - Nos. 3 \& 4)
Section 29
Eastraras
Seward Courity.

Township

State Registration No. (Required for reglacement well and late or supplemental permits).

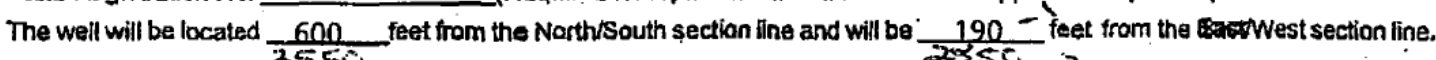

6. REPLACEMENT AND ABANDONED INFORMATION: (See Permil Restrictions-No.3) - 3

Will this weli replace a well that is or will be permanently abandoned? DYES ZNO.

Date that the original well was last operated on 20

The replacement well will be feet from the original well.

- Wall the replacement well provide water to the same tract of land as the original well? $\square$ YES $\square$ NO.

7. WELL AND LAND APPUICATION SKETCH:

The box at the right represents one square mile, (1 section). Indicate with an " $X$ ", the proposed location of the well(s), outine and cross-hatch the proposed water use area.

8. IRRIGATION OR OTHER LAND APPLICATION OF WATER: How many acres will this well apply water to? Less than 100 Type of irrigation (water distribution) system is proposed? 口Center pivot $\square$ Gated pipe UOther(speçify) Stationary 3 Span

9. PREVIOUS IRRIGATION OR OTHER LAND APPLICATION:

Are any of the acres identifed in question 8 served by another well now? DYES QNO. If YES, How many acres?

What is the current distribution system? QCenter pivot DGated plpe

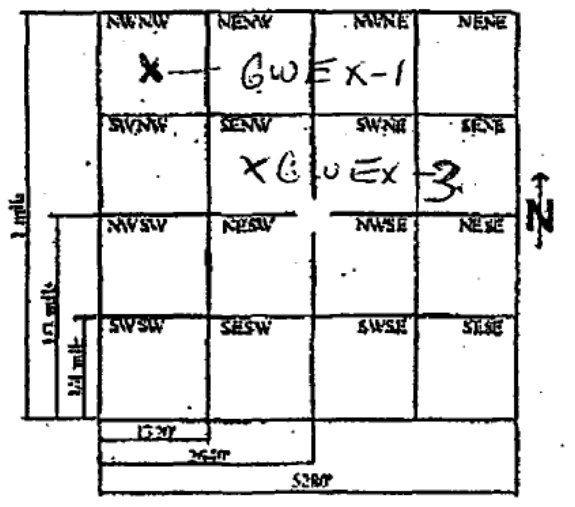
口other(specify)

10. GROUND WATER TRANSFER: (See Permit Restrictions - No. 5)

Is the proposed well to be used to transfer water outside of the legal description listed above? HES I NO.

If YES, enter the legal description of the water use area. $\frac{\text { NWSW }}{\text { SWSW }}$ Quarter, Section $\frac{20}{17}$ Township $\frac{11}{11}$ North, Range $\frac{1}{1}$ East/fWestix

11. COMMINGLED, COMBINED, CLUSTERED, OR JOINED WELLS: (Se Permis Restrictions - No. 4)

Will the groposed well be connected to another well(s) or be used to supplement an existing water use from another well(s)? IUYES 口NO. IfYES, list the State Registration No(s). of other well(s) $G-097200$ RECENED 


$$
\text { Well Identification: GWEX-1 }
$$

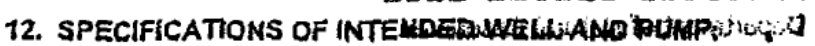

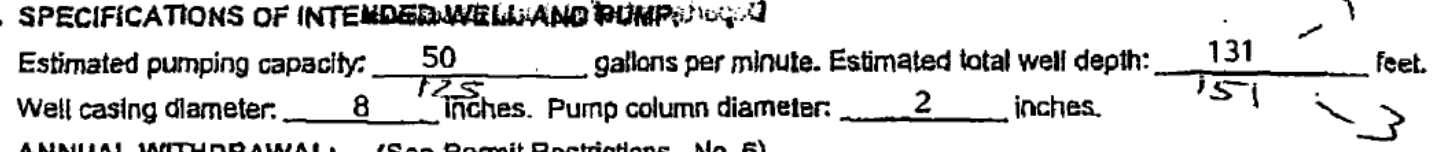

13. ANNUAL WITHDRAWAL: (See Permit Restrictions - No. 6)

is the total annuaf ground water withdrawal of all welli(s) on this parcel of land estimated to be five hundred (500) acre feet or more? DYES ZNO

If the existing well(s) on this parcel of land currently withdraw five hundred (500) acre feet or more annually, will the proposed well increase the total ground water withdrawal by two hundred and fifty $(250)$ acre feet or more? $\square$ YES 酋 NO

14. LANDOWNER CERTIFICATION: Please read permit restrictions listed below.

1, hereby, certify that I am familiar with the information contained In this applleztion and, that to the best of my knowledge and belief, the information is complete and accurate. I understand and will comply with the permil restrictions and the District's rules and regulations related to the construction and goeration of this weil.

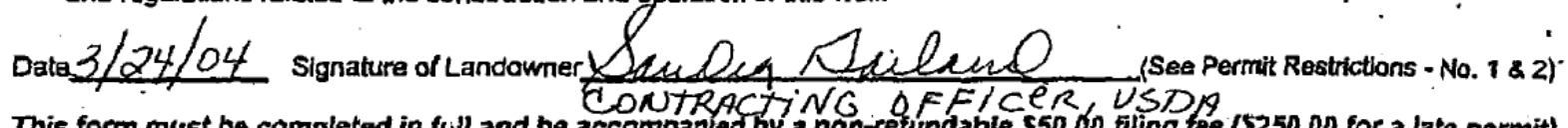

This form must be completed in full and be accompanied by a non-refundable $\$ 50.60$ filing fee (\$250.00 for a late permit) payable to the Upper Big Biue NRD, 105 Lincoln Avenue, York, Nebraska 68467 . An incomplete application will be returned for correction. A returned application must be resubmitted within 30 days or the filing fee is forfeited.

\section{PERMIT RESTRICTIONS}

1. This application must be signed by the landowner, his/her power of attorney or be accompanied by a notarized statement, signed by the landowner, authorizing the another person's signature.

2. This permit shall remain in force for one (1) year from the date approved.

3. If the well authorized by this permit has a capacily of more than fifty (60) gallons per minute, it must be constnucted at least one thousand (1000) feet from any existing well with a capacity of more than fitty $(50)$ galions per minute that is under different ownership. If a well that is less than one thousand (1000) feet from a well under separate ownership is being replaced, the replacement well may not be more than fifty $(50)$ feet closer to the well under separate ownership than the one it is replacing.

4. When water wells are commingled, comblned, clustered, or joined and have a combined total capacily of more than fifty (50) gallons per minute, each water well shall comply with well spacing as provided in Restriction No. 3.

5. A well shall nat be used to transfer ground water to a government survey section that is not adjacent to the tract of land in which the well is located. Transfers of ground water from the tract on which the well is located shail be fimited to an acreage equal to the acreage in that tract unless such transfers occurred prior to July 1, 1990.

6. If the total proposed annual ground water withdrawal from this parcel of land exceeds five hundred (500) acre feet ( 163 million gallons) or if existing well(s) currently withdraw five hundred (500) acre feet or more and the proposed well will increase the total withdrawal by two hundred and fity (250) acre feet ( 81.5 million gallons) or more, a hydrologic evaluation. must be submitted with this application in accordance with Dlstrict Rule 5, Ch. 5.

7. All wells permitted by the District on or after March 1, 2004 must be equipped with a flow meter priar to operation.

Ground Water Management Area rules and regulations are.subject to change. A copy of District Rule 5 is avallable upon request. Prior to construction or operation, the permittee should contact the NRD office if he or she has any questions abouis the rules and regulations.

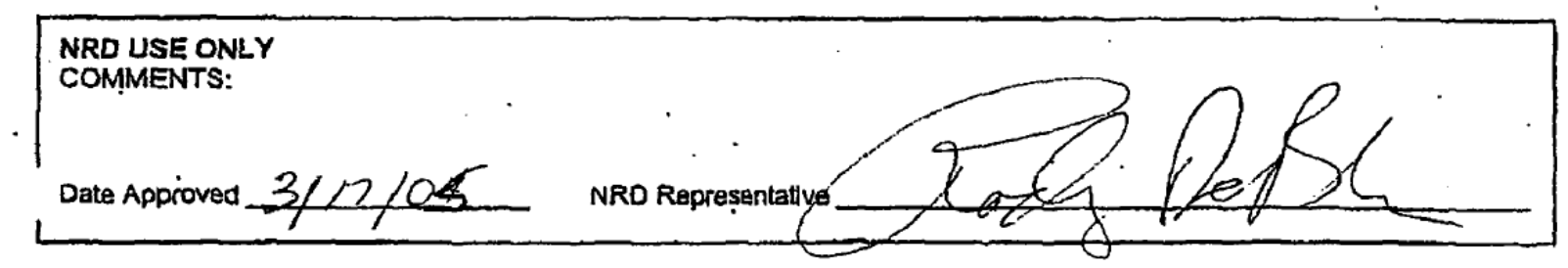

March 2004 


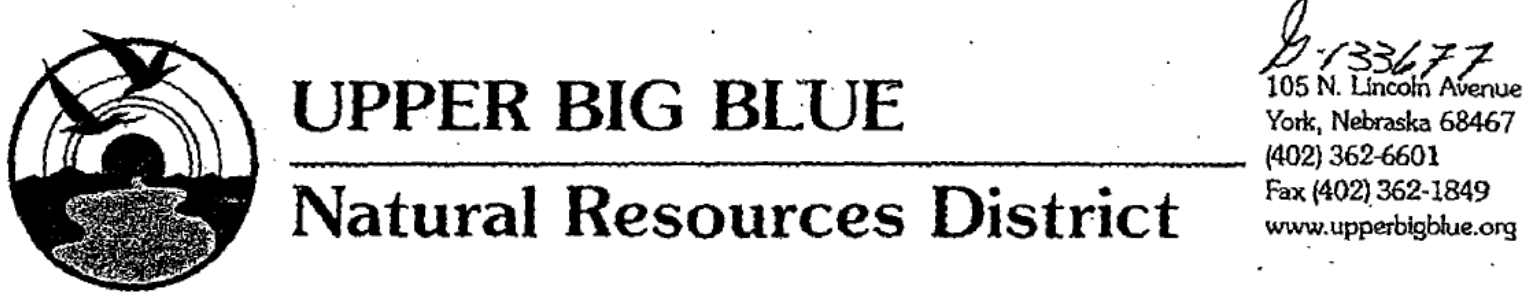

March 18, 2005

USDA/FSA

Mail Stop 4725

Room 4725 - South Building

1400 Independence Avenue

Washington, DC 20024

Subject: Late Recovery Wells Permit

Dear Sirs:

The NRD has approved the enclosed late well permit for the series of two wells, GWEX-1 and GWEX-3, located in Section 29-T11N-RIE, Seward County of the Upper Big Blue Natural Resources District Groundwater Management Area. It has been approved subject to all the restrictions listed on the permit and subject to the Management Area rules and regulations.

We will forward a copy of the well permit to the Nebraska Department of Natural Resources. If you have any questions feel free to call me at the NRD.

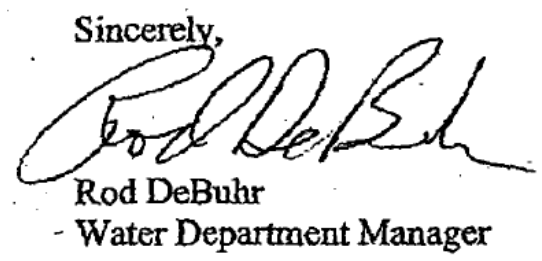

:lsh

Copy - Scott Thalacker, Boart-Longyear, Little Falls, MN Department of Natural Resources File 
Utica First-Year Review, October 2004-November 2005

Version 00, 12/12/05

\section{GWEX-4}




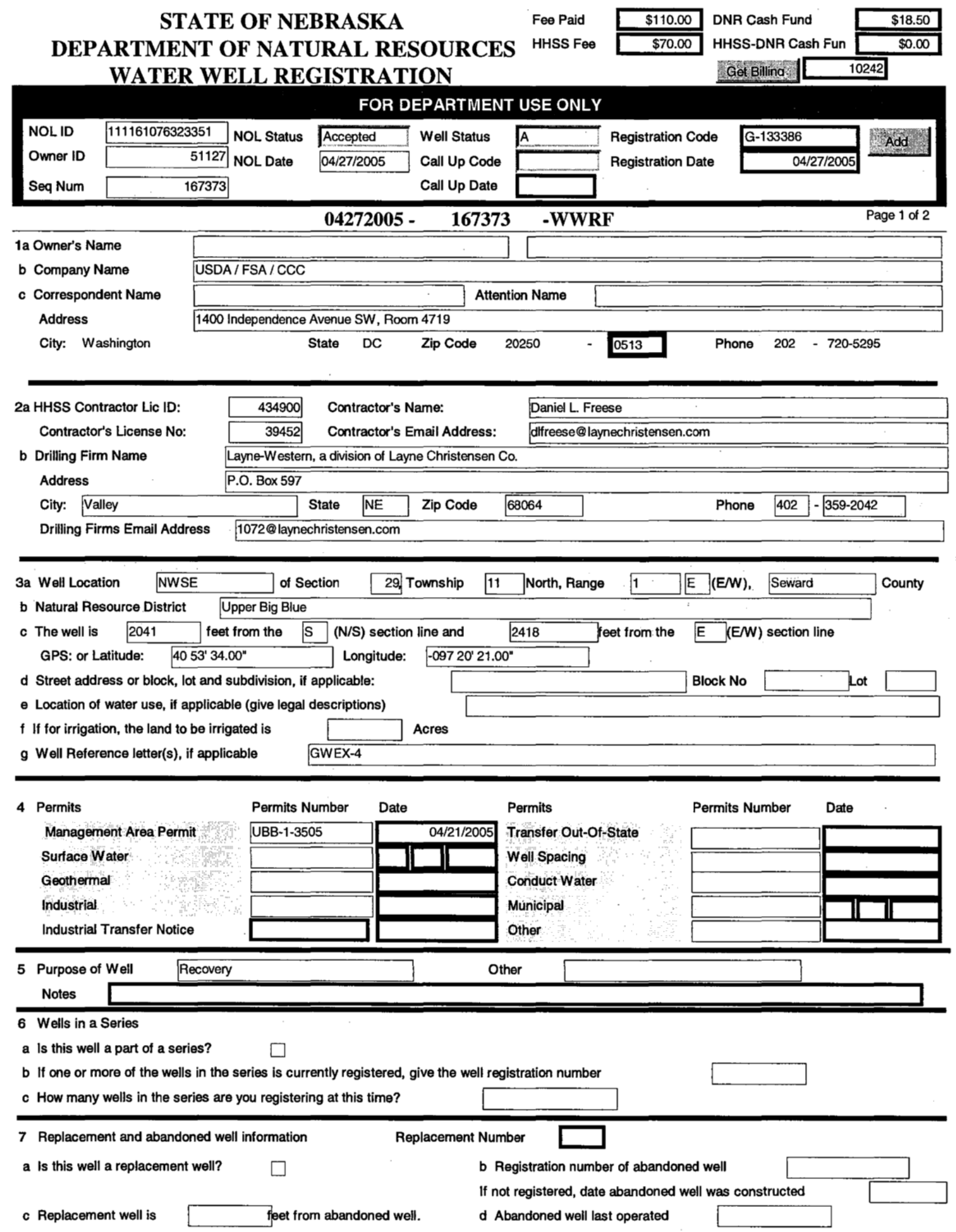


04272005 - $167373 \quad$-WWRF

Page 2 of 2

e Original well pump column size:

g Location of water use of abandoned well

inches.

f Completion of original well abandonment on

8 Pump Information

a Is pump installed at this time?

Is pump installed by well owner in section 1 ?

Else installed by pump installer.

b HHSS Installer's License ID.

Pump Installer's License No.

Pump Installer's Email Address

Pump Installer's Firm Name

Pump Installer's Firm Address

City:

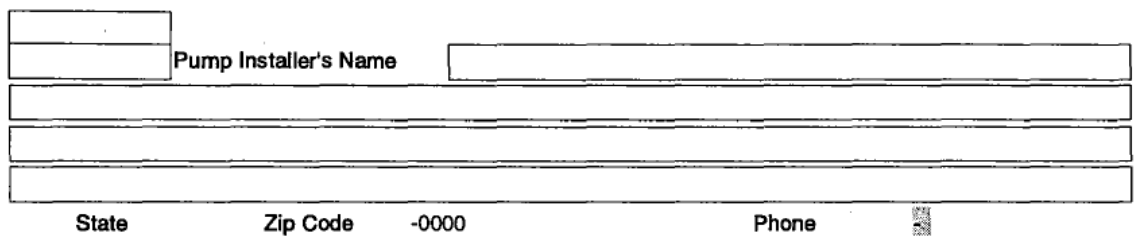

Pump Installer's Firm Email Address

c Pumping Rate $\square$ gallons per minute

d Drop pipe diameter $\square$ inches

f Pumping equipment installed

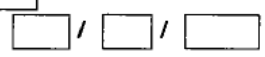

$\mathrm{h}$ This well will be used to pump less than $50 \mathrm{gpm}$

9 Well Construction Information

a Total well depth 150.0 feet.

c Pumping Water Level $\square$ feet.

e Well construction completed: $\quad 11 \quad 01 \quad 1997$

g Casing and Screen Joints Welded Other

\begin{tabular}{ll}
\hline & measured or estimated \\
e Length of drop pipe & feet.
\end{tabular}

g Pump Brand

$\square$

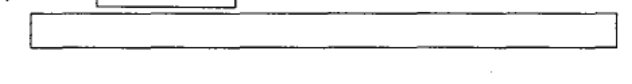

10 Well Construction (Casing and Screen)

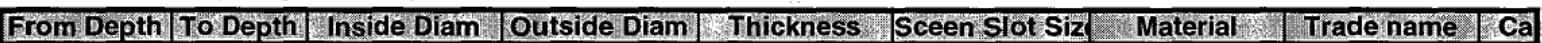

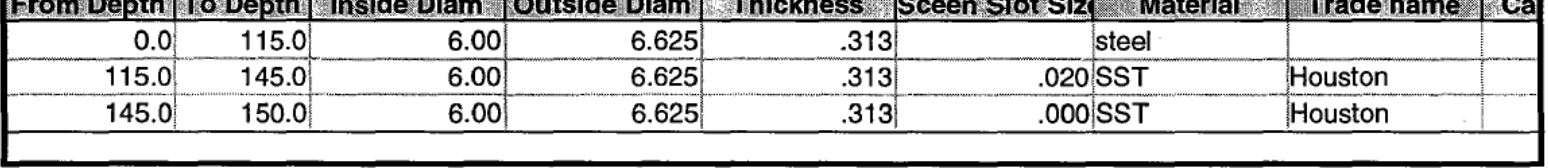

11 Well Construction (Grout and Gravel)

NOL1D $\quad$ From Depth To Depth [3]

\begin{tabular}{|c|c|c|}
\hline 111161076323 & 0.0 & 105.0 cement \\
\hline 111161076323 & 105.0 & 110.0 bentonite chips \\
\hline 111161076323 & 110.0 & 150.0 Central Sand C Pac \\
\hline
\end{tabular}

12 Geolog Material Logged

\begin{tabular}{|r|r|r|r|}
\hline NOETD & From Depth & To Depth & Description \\
\hline 111161076323 & 0.0 & 4.0 dark brown organics \\
\hline 111161076323 & 4.0 & 40.0 brown silty clay \\
\hline 111161076323 & 40.0 & 45.0 sand and gravel \\
\hline 111161076323 & 45.0 & 50.0 silty sand with some gravel \\
\hline 111161076323 & 50.0 & 86.0 fine sand, silty with trace of clay \\
\hline 111161076323 & 86.0 & 101.0 sand and gravel \\
\hline 111161076323 & 101.0 & 108.0 fine sand \\
\hline 111161076323 & 108.0 & 110.0 sand and gravel \\
\hline 111161076323 & 110.0 & 132.0 fine sand \\
\hline 111161076323 & 132.0 & 136.0 medium sand \\
\hline 111161076323 & 136.0 & 148.0 fine sand \\
\hline 111161076323 & 148.0 & 150.0 sand and gray clay \\
\hline
\end{tabular}




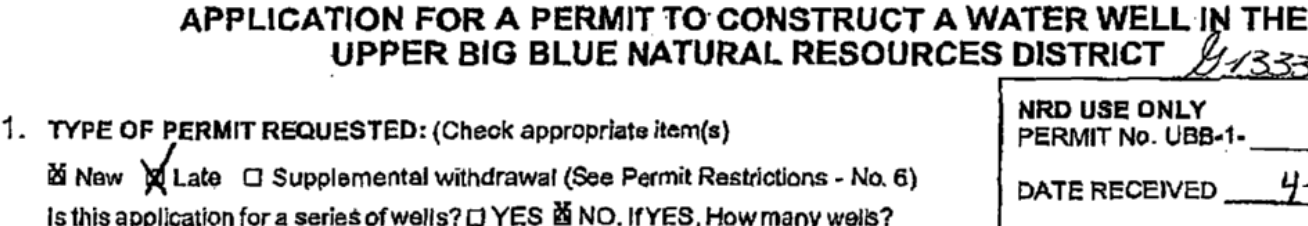

WETLL ID: GWEXX -4 Is this application for a series of wells? DYES 逼 NO. IfYES, How many wells?

3. NAME AND ADDRESS OF WELL DRILLER: Layme-Western

2. NAME AND ADDRESS OF LANDOWNER: USDA / ESA 1400 Independence Ave SW, Mail Stop 4725 Washington, DC 20250-4725 Phonel 202 ) $720 \div 5104$

4. PURPOSED USE OF WELL: (Check one) DDomestic IIndustrial DIrrigation DLivestock aPublic Water Supply YCoiner(spedly) Grounctwater Bxtraction

5. IDENYIFY THE LOCATION OF THE PROPOSED WeLL: (See Permit Restrictions. - Nos. 3 \& 4) Section 29 ,Township 11 North, Range 1 Easuragx Seward State Registration No. (Required for replacement well and lale or supplemental permits). The well will be located_2041_feet from thew/South section line and will be 2418 feet from the East/4ast section line.

6. REPLACEMENT AND ABANDONED INFORMATION: (See Permit Restrictions -No. 3)

Will this well replace a well that is or will be permanently abandoned? QYES MNO.

Date that the original well was last operated on 20

The replacement well will be feet from the original well.

Will the replacement well provide water to the same tract of land as the original well? $\square$ YES $\square$ NO.

7. WELL AND LAND APPLICATION SKETCH:

The box at the right represents one square mile, (1 section). (ndicate with an " $X "$ ", the proposed location of the well(s). outline and cross-hatch the proposed water use area.

8. IRRIGATION OR OTIHER LAND APPLICATION OF WATER:

How many acres will this well apply water lo?

Type of irrigation (water distribution) system is proposed?

口Centerpivot $\square$ Gated pipe Jther(specify)

9. PREVIOUS IRRIGATION OR OTHER LAND APPLICATION:

Are any of the acres identified in question 8 served by another well now?

DYES XNO. If YES, How many acres?

What is the current distribution system? aCenter pivat aGated pipe

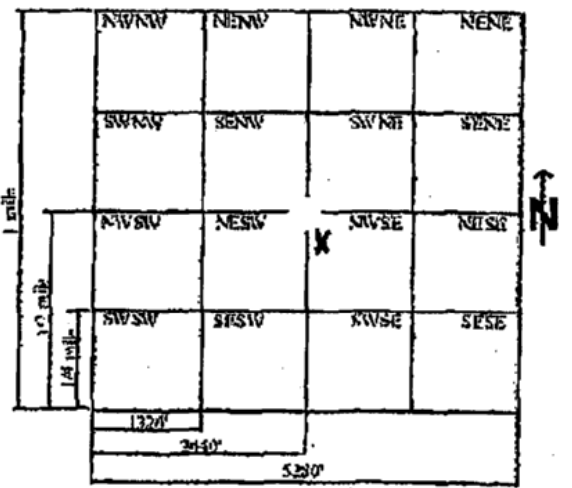

QOther(specify)

10. GROUND WATER TRANSFER: (See Permit Restrictions -No. 5) Is the proposed well to be used to transfer water outside of the legal description listed above? $D$ YES $\square$ NO.

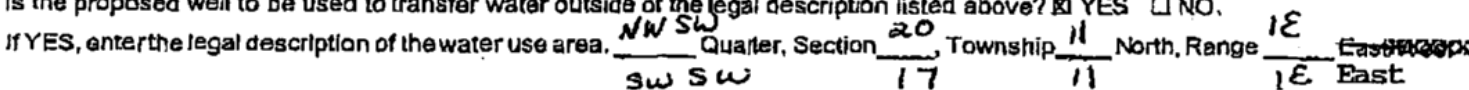

11. COMMINGLED, COMBINED, CLUSTERED, OR JOINED WELLS: (See Permil Restrictions - No. 4)

Will the proposed well be connected to another well(s) or be used to supplement an existing water use from another well(s)? $\square$ YES NO. If YES, llst the State Registation No(s). of other well(s) 

$\begin{array}{cccc}\text { APR-27-2005 WED 09:57 AM UPPER BIG BLUE NRD } \\ \text { 03/31/2985 } & 08: 12 \text { - } 2827294619\end{array}$ $\cdots-$ $.03 / 30 / 2005$ 11:55 FAX 4024755049 TCW CONSTRECTION
FAX NO, 4023621849

P. 01 USDA FSA CEPD

PAGE 05/05

12. SPECIFICATIONS OF SNTENDEO WELL AND PUMP:

D-133386

$0004 / 004$

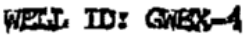

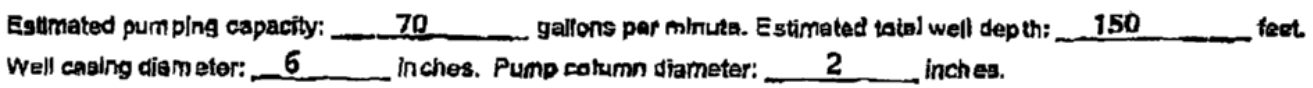

3. ANNUAl WIThdraWal: (See Pormit Restrictions - No. 6)

Is the totol annual ground water wittrirawal of all weil(s) an this parcel of land estimated to be fve hundred (500) acre feet of mone? $\square$ YES BNO

If the existing well(s) an this parcel ofland currently wilndraw five hundred $(500)$ aore faot armore annulally, will the proposed well inorease the total ground water whithawal by wo hundred and fity (250) acre feetor more? 0 YEs 2 NO

1A. LANDOWNER GERTIFICATDN: Plezse read permit restrictions liswd bolow.

I, hereby, certfy that I am femillar with the information contained in this applicetlon and, that to the boat of my knowledge and bellef, the Intormation is com plete and accurate. I und eratand and will comply whth the pormitregtrlettons and the bistricfs rules and ragulations relatad to the construction and operation of thia weill.

Date $3|31| 05$

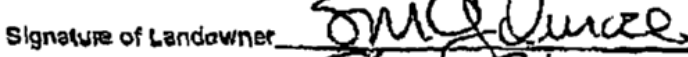
(Sea Permik Restrictions - No. 1 \& 2)

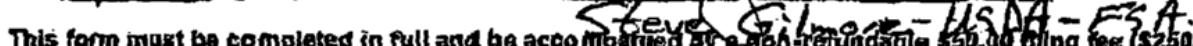

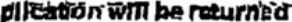
tor corrublion. A returned apploatlon muot be resubmitted within 20 days or the allng foo b forfeited.

\section{PERMIT RESTRICTONS}

1. This application must be abned by the landowner. his her power of attorney or be accompanied by a notaplzed statem ent, signed by the landowner, authorizing the ano ther person's slgn ature.

2. This permit ohall remain in fore for one (1) year from the date approved.

3. If the well authorized by this permit has a cap scity of ma re then fity (50) 9 allons par m inute, it muss be constructeat as ieast one thousand (1000) foet from any exiating weif with a capaolyy of more than fifty (sa) gallons per minute that is under different ownership. If a wall that is less than ono thousand (1000) fact from a wel undep separate ownership 15 being replaced, the replecement wall may notbe more than fity (50) fast cloger to the well unde $t$ gep arato ownership than the one 11 ie replacing.

4. When weler wells are comminglad, combined. chgtered, or Joined and have a combined total capacity of more than fitty (50) gations per minute, each watap well shall comply with woll apacing as provided in Restrictlon Ne. 9.

5. A well shal not be usod to transler ground water to a government survay sectlon that is not adjacent w the fract of land in whlch the well is localed. Transfers of ground water from the trect on which the well is located bhall be ilmited to an

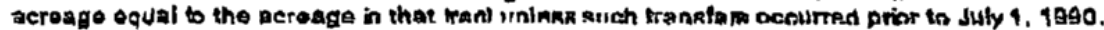

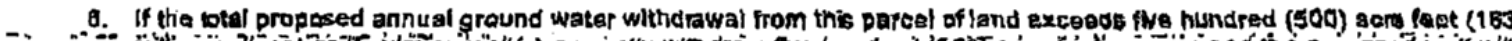

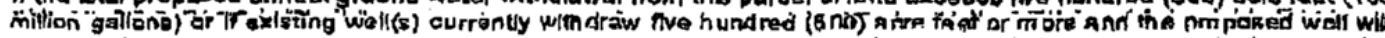
increase the latal withdrawal by two hundred and fifty $(250)$ acre fees ( $84.5 \mathrm{~m}$ llion gallons) of m ore. a hydrologic avaluation must bo subm itted with this appllcation in accordance whit Dlstict Rule S. Ch. 5 .

7. All wolls pormitted by the Dlstrict on or after March 1.2004 must be equipped with a flow meter priorto operation.

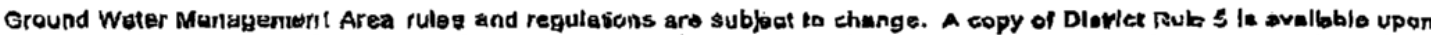
request. Prior to construotion ar operation, the permites should contact the NRD affice If he or she has sny questions about the rules and regulatons.

NRD USE ONLY

COMMENTS:

Date Approved $4 \sim 21-05$

NRD Representatlve

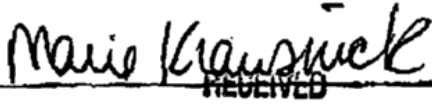

March 2004

APR 272005

MATUPAPTMENT URE

$$
\text { Received Time Apr. 27. 9:56AM }
$$


To: dlfreese@laynechristensen.com; 1072@laynechristensen.com

Re: Well Registered

April 27, 2005

04272005-167373-COR(1)

CONTRACTOR: Daniel L. Freese

CONTRACTORS FIRM:

Layne-Western, a division of Layne Christensen Co.

P.O. Box 597

Valley, NE 68064

LOCATION OF WELL:

NW1/4SE1/4 of Section 29

Township 11 North, Range $1 \mathrm{E}$

Seward County

OWNER: USDA / FSA / CCC

NOL ID: 111161076323351

SEQUENCE NUMBER: 167373

The above well has been registered with the Nebraska Department of Natural Resources. Its registration number is G-133386. The registered well information can be reviewed at the Department website: http://dnrdata.dnr.state.ne.us/wellssql

We thank you for your cooperation. If you have any questions or comments, please let us know.

Sincerely,

Christine Southwick

Staff Assistant, Ground Water

Nebraska Department of Natural Resources

Lincoln, NE 68509

(402) $471-4084$ 
Utica First-Year Review, October 2004-November 2005

Version 00, 12/12/05 
DNR

PO Box 94676

Lincoln, NE 68509-4676

Phone (402)471-2363

STATE OF NEBRASKA DEPARTMENT OF NATURAL RESOURCES WATER WELL REGISTRATION

\section{FOR DEPARTMENT USE ONLY}

Registration Date 10-3-2005 Sequence No. 170488 Registration No. G-136669 Owner Code No. 51127 Receipt No.

1. a. Well Owner's First Name

b. Company Name USDA/ CCC

c. Correspondent Name Sieve Gilmoic

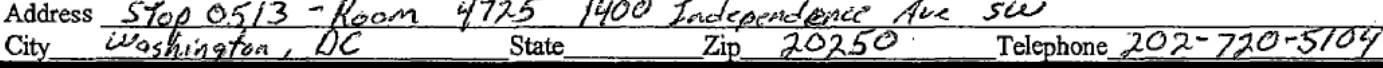

2. a. Contractor's License No_ 19193 Contractor's Name_Mike Magnin Contractor's Email Address MMaginin $ه$ bigort lenqueor ocoin

b. Drilling Firm Name Boriet Lonquear Address 101 Alderion Street City Schafield State UI Zip_54476 Telephone 715-359-7090 Drilling Firm's Email Address

3. a. Well location NE $1 / 4$ of the $N E \frac{1}{1 / 4}$ of Section 30 , Township I/ North, Range 1 E

b. Natural Resources District Upper $\mathrm{Bi}$, B/

c. The well is 249 feet from the ND $\square$ ) section line and 95 feet from the (E)

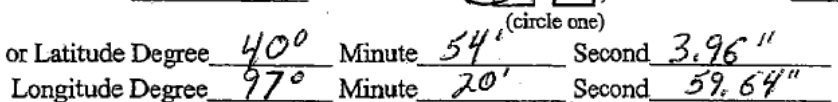

d. Street address and subdivision, if applicable

Block

e. Location of water use, if applicable (give legal descriptions)

f. If for irrigation, the land to be irrigated is

g. Well reference letter(s), if applicable

$m w 1$ acres. HHSS PWSTD

4. Permits

Management Area Permit Number

Geothermal Permit Number

Mumicipal Permit Number

Well Spacing Permit Number HHSS UPPER BIG BIUE NRD

Last Name

5. Purpose of well (indicate one) Dquaculture Demmercial/Industrial Datering (over 90 days) $\square$ Domestic $\square$ Ground Heat Exchanger $\square$ Groundwater Source Heat Pump $\square$ Irrigation $\square$ Injection Divestock Monitoring Dublic Water Supply (with spocing (46-638)) $\square$ Public Water Supply (without spacing) $\square$ Recovery $\square$ other

(indicato vse)

6. Wells in a Series.

a. Is this well a part of a series? $\square$ Yes go to part b of this section $\quad$ No go to part 7 of this application

b. If one or more of the wells in the series is currently registered, give the well registration number

c. How many wells in the series are you registering at this time?

7. Replacement and abandoned well information

a. Is this well a replacement well? $\square$ Yes

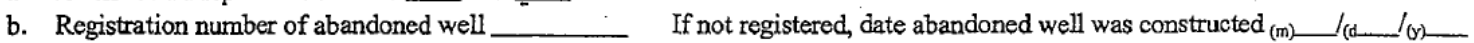

c. Replacement well is _____ feet from abandoned well. d. Abandoned well last operated $(\mathrm{m})$ ____ $/(\mathrm{d})$

e. Original well pump column size ___ inches. f. Completion of original well abandonment on $(\mathrm{m}) \ldots /(\mathrm{d}$

g. Location of water use of abandoned well 
8. Pump Information.

a. Is pump installed at this time

Is pump installed by well owner in section 1 ? YYes $\square$ No Is pump installed by contractor in section $2 ? \square \square$ Yes $\square X]$ No

If pump installed by pump installer, please fill out license number below

b. Pump Installer's License No.___ Pump Installer's Name

Pump Installer's Email Address

Pump Installer's Firm Name

Pump Installer's Firm Address

City State Zip. Telephone

Pump Installer's Firm Email Address

c. Pumping rate gallons per minute

d. Drop pipe diameter inches

f. Pumping equipment installed $(\mathrm{m}) \_/(\mathrm{d}$ $\square$ Measured $\square$ Estimated

e. Length of drop pipe

g. Pump Brand

h. This well is designed and constructed to pump less than $50 \mathrm{gpm}$ Yes

9. Well Construction Information.

a. Total well depth $105,0^{\circ}$ feet.

c. Pumping water level ____ feet

e. Well Construction completed (month) \&

g. Casing and Screen Joints are Welded (day) 101 (yar 05

b. Static water level $\quad 87.0^{\prime}$ feet

d. Well Construction began (month) $8 /$ (day) $10 /($ year 0.5

f. Bore hole diameter in inches Top $\sigma^{t 1}$ Bottom $\frac{\sigma^{\prime \prime}}{\text { day }}$

10. Well Construction (Casing \& Screen)-c, d, e, \& g measurements should be in inches to three decimal places

\begin{tabular}{|c|c|c|c|c|c|c|c|c|}
\hline & & $\mathrm{b}$ & c & $\mathrm{d}$ & $\mathrm{e}$ & $f$ & $\mathrm{~g}$ & $\mathrm{~h}$ \\
\hline $\begin{array}{r}\text { Pla } \\
\text { Dept }\end{array}$ & $\begin{array}{l}\text { ment } \\
\text { in Feet }\end{array}$ & $\begin{array}{l}\text { Casing or } \\
\text { Screen }\end{array}$ & $\begin{array}{c}\text { Inside } \\
\text { Diameter }\end{array}$ & $\begin{array}{c}\text { Outside } \\
\text { Diameter }\end{array}$ & $\begin{array}{c}\text { Wall } \\
\text { Thickness }\end{array}$ & $\begin{array}{l}\text { Screen Slot } \\
\text { Size }\end{array}$ & $\begin{array}{l}\text { Type of } \\
\text { Material }\end{array}$ & Trade Name \\
\hline From & To & & & & & & & \\
\hline 0 & $85,0^{\circ}$ & Cassing & 2.067 & 2,375 & .154 & & PVC & Boorthonouger \\
\hline $85.0^{\circ}$ & $105.0^{\prime}$ & $20,0^{\prime}$ sereen & 2,067 & 2.375 & .154 & .010 & PVC & Boast Lomerert \\
\hline & & & & & & & & \\
\hline
\end{tabular}

11. Grout and Gravel Pack

\begin{tabular}{|c|c|c|c|}
\hline \multicolumn{2}{|c|}{ Placement Depth in Feet } & \multirow{2}{*}{$\begin{array}{c}\text { Grout or } \\
\text { Gravel Pack }\end{array}$} & \multirow[t]{2}{*}{ Material Description } \\
\hline From & To & & \\
\hline$Q$ & $79.0^{1}$ & Bentonite Grout & Bordid Arso Guand Grout $30 \%$ Solids \\
\hline 79.0 & 83,0 & Bentonite Chips & Baroid $3 \mathrm{k}$ ltoleplus \\
\hline 83,0 & 108,0 & Sand $\# 20$ & Red Flint Sand If Gravel 20 well Slot Soind \\
\hline
\end{tabular}

12. Geologic Materials Logged

Depth in Feet Description

$\frac{\text { From }}{6} .5 \%$ Grovel

$.5^{\prime} 49.0^{\prime}$ Brown Silty Clay

49,0 108.0 Brown Medum to fine Sand

Depth in Feet

From To

Description

(Additional sheets may be submitted)

13. I am familiar with the information submitted on this registration, and to the best of my knowledge it is true.

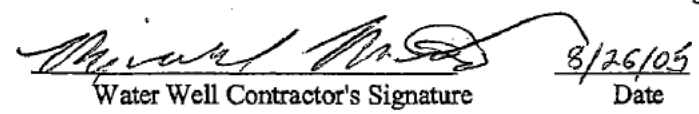

Water Well Contractor's Signature

Date

Well Owner's Signature

Date

if Contractor is unknown or Deceased 


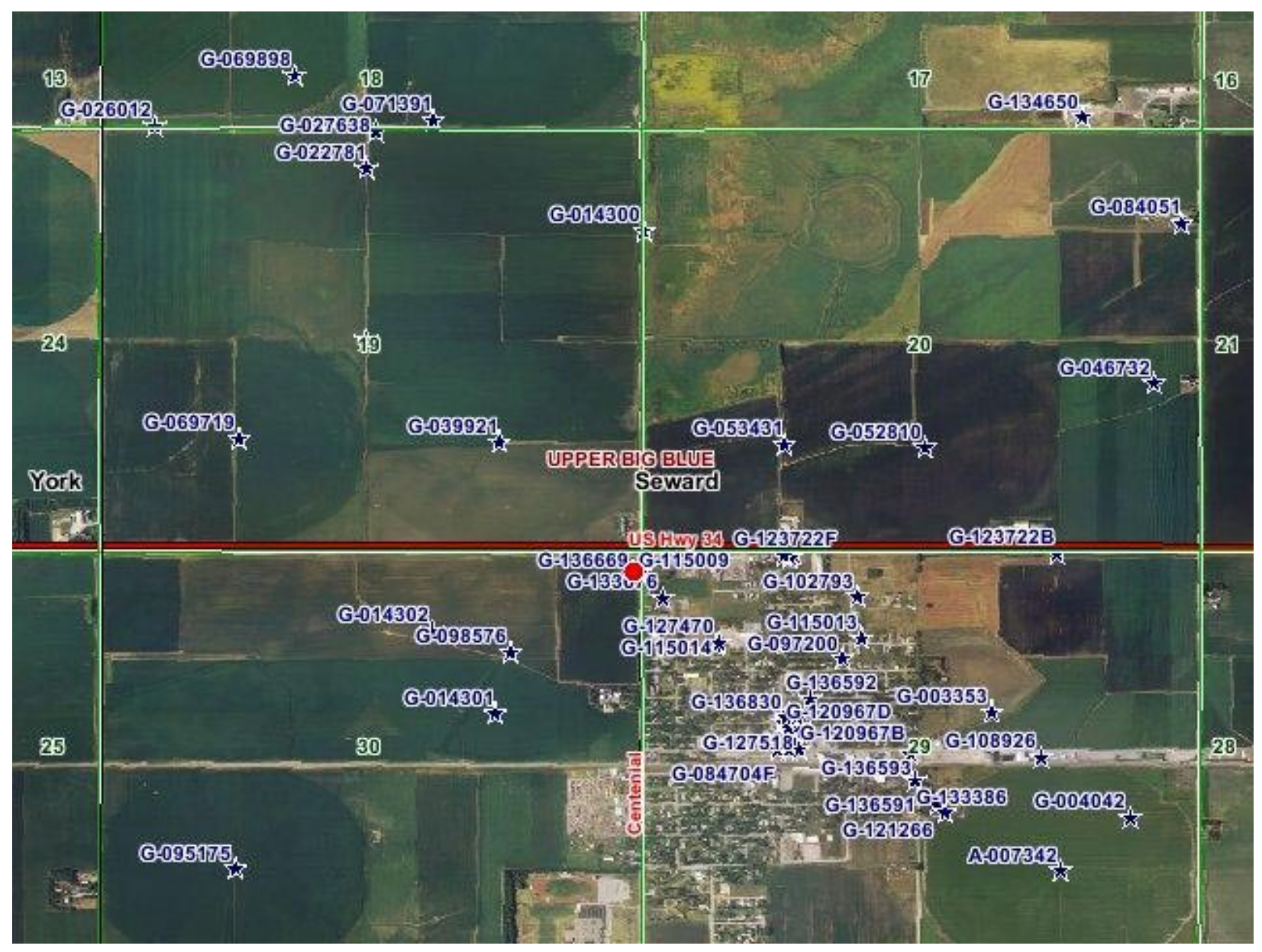


Utica First-Year Review, October 2004-November 2005

Version 00, 12/12/05

A-33

MW2 
STATE OF NEBRASKA

\section{DEPARTMENT OF NATURAL RESOURCES}

WATER WELL REGISTRATION

\section{FOR DEPARTMENT USE ONLY}

Registration Date $10-3-2005$ Sequence No. 170489 Registration No. G-136591 Owner Code No. 51127 Receipt No.

a. Well Owner's First Name

b. Company Name USDA/CCC

c. Correspondent Name Stewe Gilmore 1400 Tadependence

City Washington, DC State UPPER BIG BLUE

2. a. Contractor's License No $19193^{\circ}$ Contractor's Name MiKe Magnin Contractor's Email Address Mmagnin Q boartlongyear a com

b. Drilling Firm Name Boint bongyear Address 101 Alderson strect City Siboficld State WI Zip 54452 Telephone 215-359-7090 Drilling Firm's Email Address

Last Name

3. a. Well location $N E_{1 / 4}$ of the SW $1 / 4$ of Section 29 , Township // North, Range / ED]W Tewaid County.

b. Natural Resources District Upper Bis B/oe

c. The well is 2451 feet from the $(\mathrm{N})$ (circle one) or Latitude Degree $40^{\circ}$ Minute $53^{\text {(circle one) }}$ Second $38.04^{\prime \prime}$ Longitude Degree 97 Minute $20^{\prime}$ Second $24,72^{\prime \prime}$

d. Street address and subdivision, if applicable Block

e. , Location of water use, if applicable (give legal descriptions)

f. If for irrigation, the land to be irrigated is

g. Well reference letter(s), if applicable

$\mathrm{mW} \cdot \mathbf{z}$ acres. HHSS PWSID

Management Area Permit Number

Geothermal Permit Number

Municipal Permit Number

Well Spacing Permit Number HHSS

Surface Water Permit Number

Industrial Permit Number

Transfer Out-Of-State Permit Number

Conduct Permit Number

Other Permit Number NDEQ

5. Purpose of well (indicate one)
Domestic
Livestock

6. Wells in a Series.

a. Is this well a part of a series? $\square$ Yes go to part b of this section $\square$ No go to part 7 of this application

b. If one or more of the wells in the series is currently registered, give the well registration number

c. How many wells in the series are you registering at this time?

7. Replacement and abandoned well information.

a. Is this well a replacement well? … Yes No

b. Registration number of abandoned well

c. Replacement well is feet from abandoned well.

e. Original well pump column size inches. g. Location of water use of abandoned well

If not registered, date abandoned well was constructed $(\mathrm{m})$ d. Abandoned well last operated (m)__ $/(\mathrm{d})$ f. Completion of original well abandonment on $(\mathrm{m}) /(\mathrm{d}$ 
8. Pump Information.

a. Is pump installed at this time $\square$ Yes $\square$ No

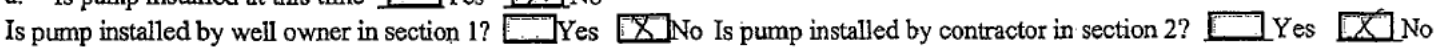

If pump installed by pump installer, please fill out license number below

b. Pump Installer's License No. Pump Installer's Name

Pump Installer's Email Address

Pump Installer's Firm Name

Pump Installer's Firm Address

City State Zip Telephone

Pump Installer's Firm Email Address

c. Pumping rate gallons per minute

d. Drop pipe diameter inches

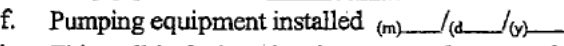

$\square$ Measured _ $\square$ Estimated

This well is designed and constructed to pump less than $50 \mathrm{gpm}$ Y Yes

9. Well Construction Information.
a. Total well depth $1 / 7,0^{\circ}$ feet.
b. Static water level 87.0 feet.

c. Pumping water level ___ feet

e. Well Construction completed (morth) 8

g. Casing and Screen Joints are Welded (man) (ver-0.5

d. Well Construction began (month) $8 /$ (day) $9 /$ (year 05

f. Bore hole diameter in inches Top_ 6 Bottom 6

Other

10. Well Construction (Casing \& Screen)- c, d, e, \& g measurements should be in inches to three decimal places

\begin{tabular}{|c|c|c|c|c|c|c|c|c|}
\hline 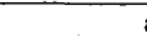 & & $\mathrm{b}$ & c & $\mathrm{d}$ & $\mathrm{e}$ & $f$ & $\mathrm{~g}$ & $\mathrm{~h}$ \\
\hline $\begin{array}{l}\text { Place } \\
\text { Depth }\end{array}$ & $\begin{array}{l}\text { ment } \\
\text { in Feet }\end{array}$ & $\begin{array}{l}\text { Casing or } \\
\text { Screen }\end{array}$ & $\begin{array}{c}\text { Inside } \\
\text { Diameter }\end{array}$ & $\begin{array}{c}\text { Outside } \\
\text { Diameter }\end{array}$ & $\begin{array}{c}\text { Wall } \\
\text { Thickness }\end{array}$ & $\begin{array}{c}\text { Screen Slot } \\
\text { Size }\end{array}$ & $\begin{array}{l}\text { Type of } \\
\text { Material }\end{array}$ & Trade Name \\
\hline From & To & & & & & & & \\
\hline 0 & $90.0^{\circ}$ & Cosing & 2.067 & 2.375 & .154 & & PVC & Beart Longyear \\
\hline $90,0^{\circ}$ & $115.0^{\circ}$ & $25.0^{i} \mathrm{Serec}$ & 2.062 & 2.375 & .154 & .010 & PUC & Bonest hongyens \\
\hline & & & & & 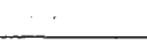 & & & \\
\hline & & & & & & & & \\
\hline
\end{tabular}

11. Grout and Gravel Pack

\begin{tabular}{|c|c|c|c|}
\hline \multicolumn{2}{|c|}{ Placement Depth in Feet } & Grout or & Material Description \\
\hline From & To & Gravel Pack & \\
\hline 0 & 85.0 & Bentonite Giout & Buroid Aaga Guard Groot $30 \%$ solids \\
\hline $85,0^{\circ}$ & $88.0^{\prime}$ & Bentonite chips & Baroid 3/8 \\
\hline $88.0^{\prime}$ & $117: 0^{\prime}$ & Sand $\# 20$ & Red Flint Sond o Gravel "zo well slot Sand \\
\hline
\end{tabular}

12. Geologic Materials Logged

$\frac{0}{15} \frac{.5}{32.0} \frac{\text { Topth in Feet }}{\text { From Soil }} \frac{\text { Top }}{1170} \frac{\text { Groy Silty Cloy }}{\text { Brown Fine-Medion Soind }}$

(Additional sheets may be submitted)

13. I am familiar with the information submitted on this registration, and to the best of my knowledge it is true.

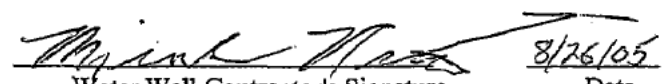

Water Well Contractor's Signature
Date

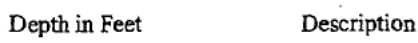

From To

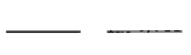

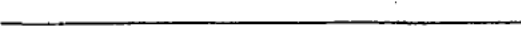
feet 


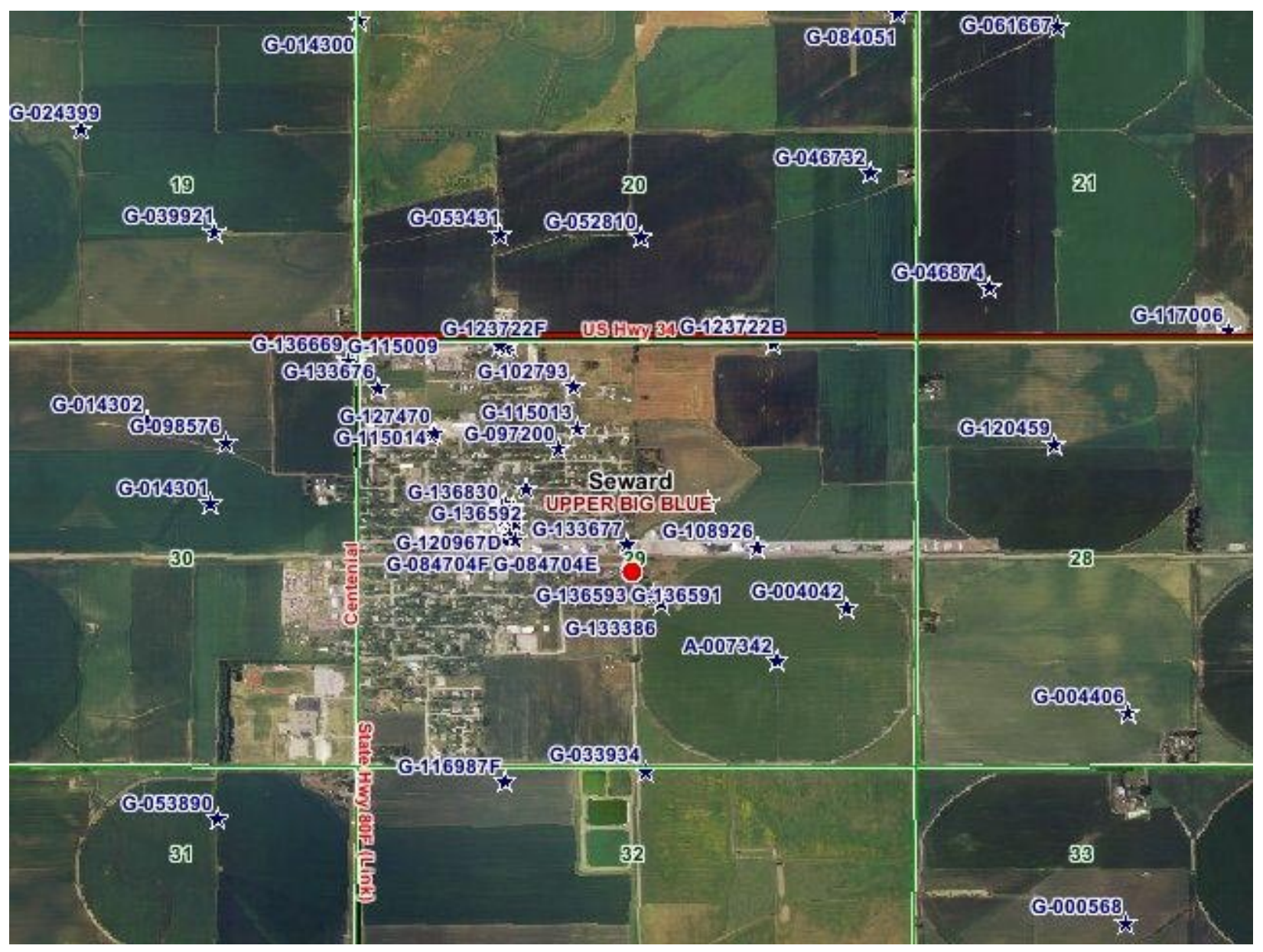


Utica First-Year Review, October 2004-November 2005

Version 00, 12/12/05

\section{MW3}


STATE OF NEBRASKA

\section{DEPARTMENT OF NATURAL RESOURCES}

WATER WELL REGISTRATION

\section{FOR DEPARTMENT USE ONLY}

Registration Date 10-3-2005 Sequence No. 170490 Owner Code No. 51127 Receipt No.

Registration No. G-136592 UPPER BIG BLUE NRD

1. a. Well Owner's First Name

b. Company Name USOA/CCC

c. Correspondent Name Sfeve Gilmore Address Stop $0513-$ Room 4725 1400 Independence

Last Name

2. a. Contractor's License No 19193 Contractor's Name_Mike Magnin Contractor's Email Address Mmagnin o bronflongyear $\cdot \mathrm{Com}$

b. Drilling Firm Name Bonirt Lengyear Address $\frac{101 \text { Aldersoin sireet }}{\text { Sehotield State WI Zip } 54476 \quad \text { Telephone } 715-359-7090}$ Drilling Firm's Email Address

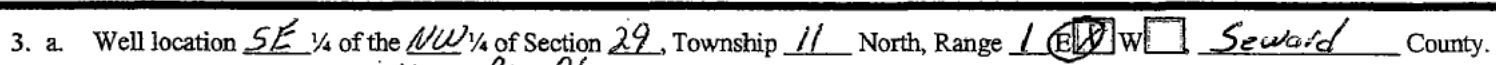

b. Natural Resources District Upper Biq Blve

c. The well is 1854 feet from the (NDSS) section line and 1594 feet from the (BDDion section line or Latitude Degree_ $40^{\circ}$ Minute $53^{\circ}$ (circle one) Second $48.12^{\prime \prime}$ Longitude Degree $97^{\circ}$ Minute $20^{\circ}$ Second $37,68^{\prime \prime}$

d. Street address and subdivision, if applicable Block

e. Location of water use, if applicable (give legal descriptions)

f. If for irrigation, the land to be irrigated is

g. Well reference letter(s), if applicable $m \mathrm{~m}-3$ acres. HHSS PWSID

4. Permits

Management Area Permit Number

Geothermal Permit Number

Municipal Permit Number

Well Spacing Permit Number HHSS

5. Purpose of well (indicate one) Aquaculture

Commercial/Industrial Dewatering (over 90 days)

Domestic $\square$ Ground Heat Exchanger $\square$ Groundwater Source Heat Pump $\square$ Irrigation $\square$ Injection $\square$ Public Water Supply (wiht ppecing (46-638) Public Water Supply (withoot spocing) $\square$ Recovery $\square$ Other

\section{Wells in a Series.}

a. Is this well a part of a series? $\square$ Yes go to part b of this section $\quad$ No go to part 7 of this application

b. If one or more of the wells in the series is currently registered, give the well registration number

c. How many wells in the series are you registering at this time?

7. Replacement and abandoned well information.

a. Is this well a replacement well? $\square$ yes No

b. Registration number of abandoned well Surface Water Permit Number

Industrial Permit Number

Transfer Out-Of-State Permit Number

Conduct Permit Number

Other Permit Number NDEQ

c. Replacement well is feet from abandoned well

e. Original well pump column size ____ inches.

If not registered, date abandoned well was constructed $(\mathrm{m})$

g. Location of water use of abandoned well 
8. Pump Information.

a. Is pump installed at this time

Is pump installed by well owner in section 1 ? Wes $\square$ No Is pump installed by contractor in section 2? $\square$ Yes $\square$ No If pump installed by pump installer, please fill out license number below

b. Pump Installer's License No. Pump Installer's Name

Pump Installer's Email Address

Pump Installer's Firm Name

Pump Installer's Firm Address

City State Zip Telephone

Pump Installer's Firm Email Address

c. Pumping rate gallons per minute

d. Drop pipe diameter inches

1_Measured $\square$ Estimated

f. Pumping equipment installed $(\mathrm{m}) /\left(\mathrm{d} \_/ \mathrm{v}\right)$ g. Pump Brand

h. This well is designed and constructed to pump less than $50 \mathrm{gpm} \square$ Yes $\square$ No

9. Well Construction Information.
a. Total well depth $125.0^{\prime}$ feet.
b. Static water level $\quad 87,0^{\prime}$ feet.

c. Pumping water level _ feet

e. Well Construction completed (month) \&

g. Casing and Screen Joints are Welded (day)

d. Well Construction began (monti) $8 /$ (day) $11 /$ (year 05

f. Bore hole diameter in inches Top_ $\sigma^{\prime \prime}$ Bottom $\sigma^{\prime \prime}$

10. Well Construction (Casing \& Screen)- c, d, e, \& g measurements should be in inches to three decimal places

\begin{tabular}{|c|c|c|c|c|c|c|c|c|}
\hline & & $\mathrm{b}$ & c & $\bar{d}$ & $\mathrm{e}$ & $f$ & g & h \\
\hline $\begin{array}{r}\text { Plac } \\
\text { Depth }\end{array}$ & ment & Casing or & Inside & Outside & Wall & Screen Slot & Type of & Trade Name \\
\hline From & T & & & & & & & \\
\hline 0 & $100.0^{\prime}$ & Casing & 2.067 & 2.375 & 254 & & PVC & Bocert Longyear \\
\hline $100.0^{\prime}$ & $125.0^{\circ}$ & 25,0 scieent & 2.067 & 2.375 & .154 & $\therefore 010$ & PVC & Borit Lenoyror \\
\hline & & & & & & & & \\
\hline & & & & & & & & \\
\hline
\end{tabular}

11. Grout and Gravel Pack

\begin{tabular}{|c|c|c|c|}
\hline \multicolumn{2}{|c|}{ Placement Depth in Feet } & \multirow{2}{*}{$\begin{array}{l}\text { Grout or } \\
\text { Gravel Pack }\end{array}$} & \multirow[t]{2}{*}{ Material Description } \\
\hline From & To & & \\
\hline 0 & $93.0^{\prime}$ & Bentonite Grout & Baroid Aqua Guard Grout $30 \%$ solids \\
\hline $93,0^{\prime}$ & $98,0^{\circ}$ & Bentonite Chips & Baroid 3/s thaleplas \\
\hline 98,0 & $128: 0^{\prime}$ & Sand *20 & Red Flint Sand \& Gravel \#20 well slot sand \\
\hline
\end{tabular}

12. Geologic Materials Logged

Depth in Feet Description

From To 0 ropsoil

.5 440 Brown silty Clay

$440^{\circ}$ 128: $0^{\circ}$ Brown Fine to Medium Sand

(Additional sheets may be submitted)

13. I am familiar with the information submitted on this registration, and to the best of my knowledge it is true.

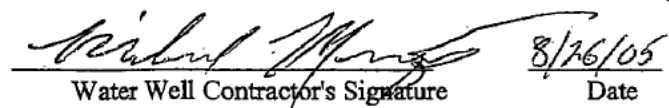

Date

Well Owner's Signature 


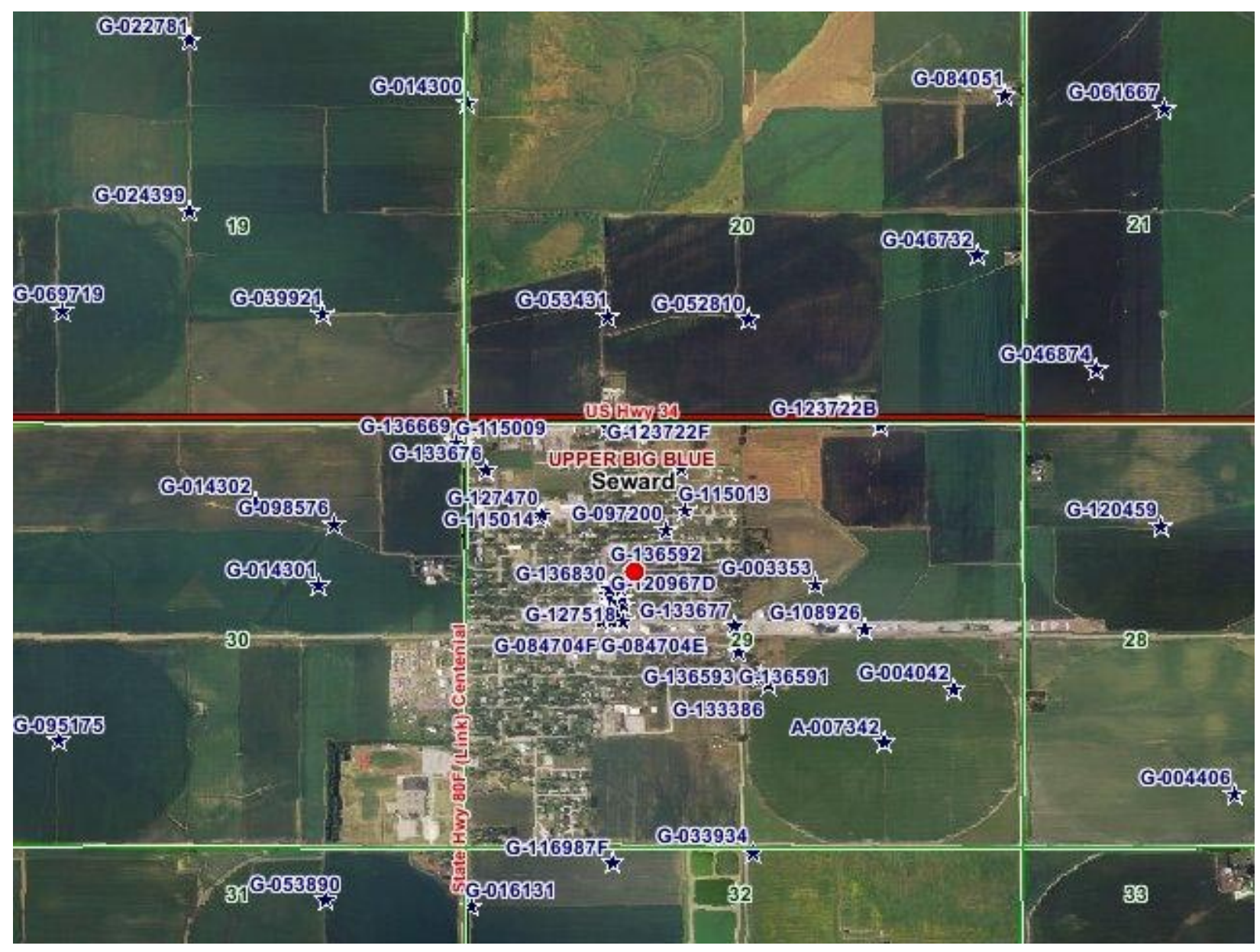


Utica First-Year Review, October 2004-November 2005

Version 00, 12/12/05 


\section{Mail to}

DNR

PO Box 94676

Lincoln, NE 68509-4676

Phone (402)471-2363
STATE OF NEBRASKA

DEPARTMENT OF NATURAL RESOURCES

WATER WELL REGISTRATION

\section{FOR DEPARTMENT USE ONLY}

Registration Date 10-3-2005 Sequence No. 170491

Registration No. G-136593

Owner Code No. 51127 Receipt No. UPPen BIGBLUE NRD

1. a. Well Owner's First Name

b. Company Name USDA/FSA /CEPD

c. Correspondent Name Siteve Gilmore Address Stop 0513 - -400 Attention

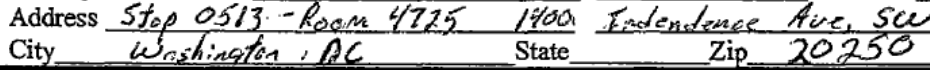

Telephone $202-720-5104$

2. a. Contractor's License No 19193 Contractor's Name Mike Mognin Contractor's Email Address Mmagnin Q hoortlongyerer e cdin

b. Drilling Firm Name Bosit Longgear Address 10 i Aiderson Sitreet City Schatield State WI Zip 5 i 1476 Telephone Drilling Firm's Email Address

3. a. Well location NE $1 / 4$ of the $5 W_{1 / 4}$ of Section 29 . Township $I /$ North, Range 1 X $\square[$ Seward County.

b. Natural Resources District Upper Big Blue

c. The well is 2451 feet from the (NT fircle one) or Latitude Degree_ $40^{\circ}$ Minute $53^{\circ}$ Second $38,07^{\prime \prime}$ Longitude Degree $97^{\circ}$ Minute $20^{\prime}$ Second $24.72^{\prime \prime}$

d. Street address and subdivision, if applicable Block Lot

e. Location of water use, if applicable (give legal descriptions)

f. If for irrigation, the land to be irrigated is

g. Well reference letter(s), if applicable acres.

4. Permits

Management Area Permit Number

Geothermal Permit Number

Municipal Permit Number

Well Spacing Permit Number

HHSS

$$
m w-4
$$
HHSS PWSD

5. Purpose of well (indicate one) L. Lquaculture [ ] Commercial/Industrial Dewatering (over 90 days) Divomestic 1 Ground Heat Exchanger $\square$ Groundwater Source Heat Pump $\square$ Public Water Supply (without spacing) $\square$ Recovery $\square$ Other

(indicato uss)

\section{Wells in a Series.}

a. Is this well a part of a series? $\square$ Yes go to part b of this section $\square$ No go to part 7 of this application

b. If one or more of the wells in the series is currently registered, give the well registration number

c. How many wells in the series are you registering at this time?

7. Replacement and abandoned well information.

a. Is this well a replacement well? $\square$ Yes $\square$ No

b. Registration number of abandoned well

c. Replacement well is

e. Original well pump column size feet from abandoned well
inches.

g. Location of water use of abandoned well

If not registered, date abandoned well was constructed $(\mathrm{m})$

d. Abandoned well last operated $(m)$ $f_{\text {(d) }} /(\mathrm{m})$

f. Completion of original well abandonment on $(\mathrm{m})$ 


\section{Pump Information.}

a. Is pump installed at this time $\square$ Yes

Is pump installed by well owner in section 1 ? $\square$ Yes $\square$ No Is pump installed by contractor in section 2 Y $\square$ Yes

If pump installed by pump installer, please fill out license number below

b. Pump Installer's License No._ Pump Installer's Name

Pump Installer's Email Address

Pump Installer's Firm Name

Pump Installer's Firm Address

City State Zip Telephone

Pump Installer's Firm Email Address

c. Pumping rate _ gallons per minute _ $\square$ Measured

d. Drop pipe diameter _____ inches e. Length of drop pipe ________eet

f. Pumping equipment installed $(\mathrm{m}) \_/\left(\mathrm{d} \_/ \mathrm{v}\right) \_$g. Pump Brand

h. This well is designed and constructed to pump less than $50 \mathrm{gpm} \square$ Yes

9. Well Construction Information.

a. Total well depth $125,0^{\prime}$ feet.

c. Pumping water level __ feet

e. Well Construction completed (month) $_{8}$

e. Well Construction completed (month) $8 /$ (day) $/ 2 /$ (yer 05

b. Static water level $8,2,0$ feet.

d. Well Construction began $($ month) $\& /$ (day) $12 /$ (year 05

f. Bore hole diameter in inches Top_6 "Bottom 6 "

Threaded $\mathrm{X}$

Other

10. Well Construction (Casing \& Screen)- c, d, e, \& g measurements should be in inches to three decimal places

\begin{tabular}{|c|c|c|c|c|c|c|c|c|}
\hline & & $\mathrm{b}$ & c & $\mathrm{d}$ & $\mathrm{e}$ & $\mathrm{f}$ & g & $\mathrm{h}$ \\
\hline $\begin{array}{r}\text { Plac } \\
\text { Depth }\end{array}$ & $\begin{array}{l}\text { ment } \\
\text { in Feet }\end{array}$ & $\begin{array}{l}\text { Casing or } \\
\text { Screen }\end{array}$ & $\begin{array}{c}\text { Inside } \\
\text { Diameter }\end{array}$ & $\begin{array}{l}\text { Outside } \\
\text { Diameter }\end{array}$ & $\begin{array}{c}\text { Wall } \\
\text { Thickness }\end{array}$ & $\begin{array}{c}\text { Screen Slot } \\
\text { Size }\end{array}$ & $\begin{array}{l}\text { Type of } \\
\text { Material }\end{array}$ & Trade Name \\
\hline From & To & & & & & & & \\
\hline Q & $100.0^{\circ}$ & Cosing & 2.067 & 2,375 & .154 & & PUC & Boart Longyear \\
\hline $100.0^{\circ}$ & $125.0^{\circ}$ & $250^{\circ}$ sereed & 2.067 & 2.375 & .154 & .010 & PUC & Boort hongyear \\
\hline & & & & & & & & \\
\hline & & & & & & & & \\
\hline
\end{tabular}

11. Grout and Gravel Pack

\begin{tabular}{|c|c|c|c|}
\hline \multicolumn{2}{|c|}{ Placement Depth in Feet } & \multirow{2}{*}{$\begin{array}{c}\text { Grout or } \\
\text { Gravel Pack }\end{array}$} & \multirow[t]{2}{*}{ Material Description } \\
\hline From & To & & \\
\hline 0 & $940^{1}$ & Bentouite Gront & Brocid Aour braid Grout $30 \%$ Solids \\
\hline $94,0^{\prime}$ & $98.0^{\prime}$ & Rentonite Chips & Baroid 3/a Holestug \\
\hline $980^{\circ}$ & $128,0^{\prime}$ & Sand $\# 20$ & Red Hint Sand t bravel ta well slot Sand \\
\hline
\end{tabular}

12. Geologic Materials Logged

Depth in Feet Description

From To $15^{-1} \quad$ fravel

$15^{\circ} 40.0^{\circ}$ Brown Silty Cloy

40,0' $128,0^{\circ}$ Browa Fine to Medium Sand

(Additional sheets may be submitted)

Depth in Feet Description

From To

$\longrightarrow$

$-1$

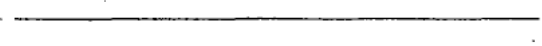

13. I am familiar with the information submitted on this registration, and to the best of my knowledge it is true.

13. I am familiar with the information submitted on this regis 8/26/05 


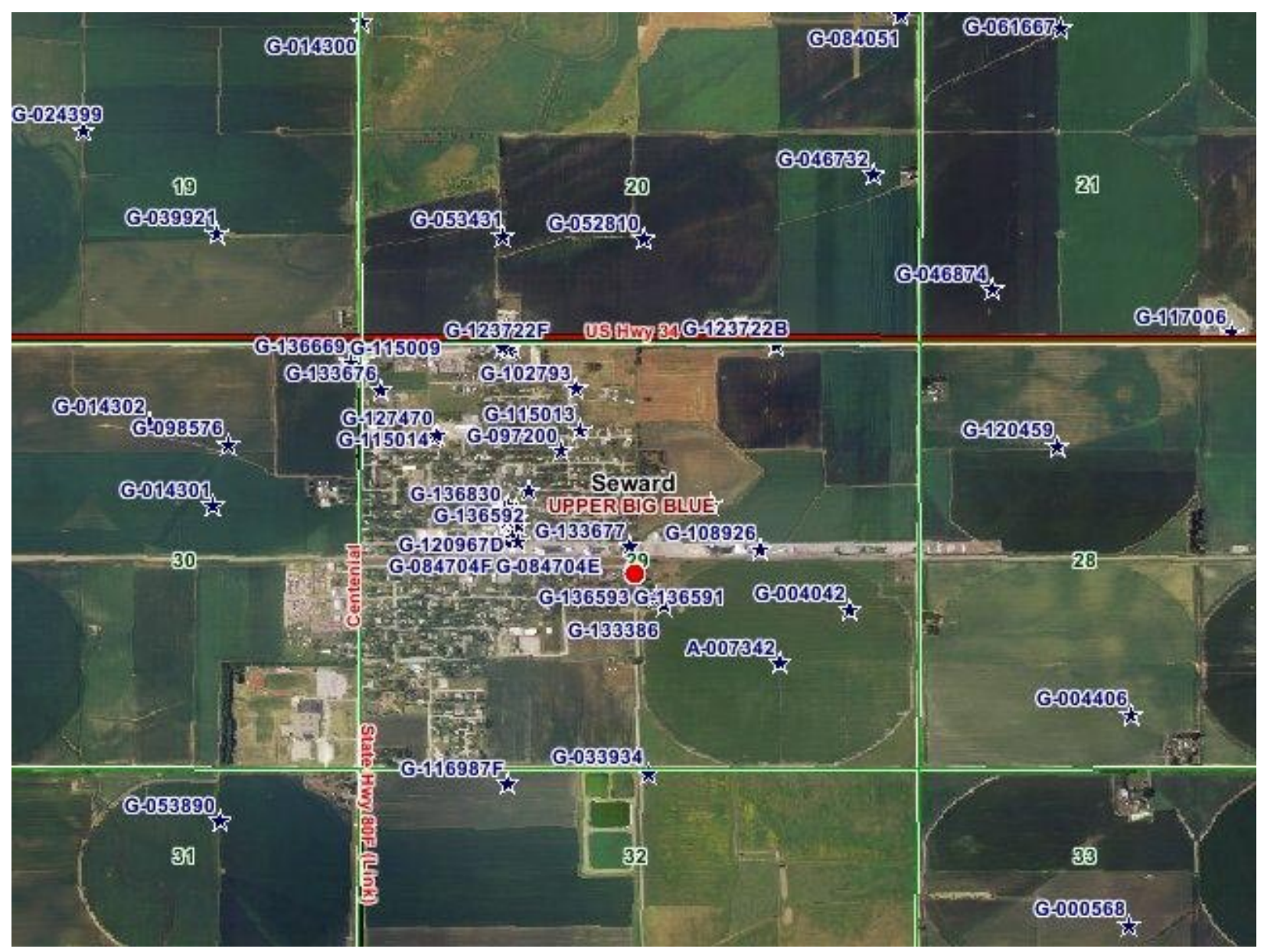

